\title{
Synthesis and Characterization of Schiff Base Metal Complexes Derived from Cefotaxime with $1 H$-indole-2,3-dione (Isatin) and 4-N,N-dimethyl-aminobenzaldehyde
}

\author{
Ahlam Jameel Abdulghani*, Rasha Khuder Hussain \\ Department of Chemistry, College of Science, University of Baghdad, Baghdad, Iraq \\ Email: ahlamjameel@scbaghdad.edu.iq
}

Received 10 July 2015; accepted 28 August 2015; published 31 August 2015

Copyright (C) 2015 by authors and Scientific Research Publishing Inc.

This work is licensed under the Creative Commons Attribution International License (CC BY). http://creativecommons.org/licenses/by/4.0/

cC) (7) Open Access

\section{Abstract}

This work involved the synthesis of two Schiff base derivatives of cefotaxime antibiotic (CFX) namely: [sodium3-(acetoxymethyl)-7-((Z)-2-(methoxyimino)-2-(2-((E)-2-oxoindolin-3-ylide-neamino) thiazol-4-yl)acetamido)-8-oxo-5-thia-1-azabicyclo[4.2.0]oct-2-ene-2-carboxylate]. (0.5) Methanol $\left(\mathrm{L}_{\mathrm{I}}\right)$ and [sodium3-(acetoxymethyl)-7-((2Z)-2-(2-(4-dimethylamino) benzylideneamino) thiazol-4yl)-2-(methoxyimino)acetamido)-8-oxo-5-thia-1-azabicyclo [4.2.0] oct-2-ene-2-carboxylate]. (0.5) Methanol $\left(\mathrm{L}_{\text {III }}\right)$ from the condensation reaction of the antibiotic with $1 \mathrm{H}$-Indole-2,3-dione(isatin) and - $\mathrm{N}, \mathrm{N}$-dimethyl amino benzaldehyde respectively. Metal complexes of the two Schiff base ligands with $\mathrm{Co}(\mathrm{II}), \mathrm{Ni}(\mathrm{II}), \mathrm{Cu}(\mathrm{II}), \mathrm{Cd}(\mathrm{II}), \mathrm{Pd}(\mathrm{II})$ and $\mathrm{Pt}(\mathrm{IV})$ ions were prepared by reacting each ligand with the metal salts in refluxing ethanol. The chemical structures of the two ligands as well as the stereo-chemical structures and geometries of the studied metal complexes were suggested depending the results obtained from CHN and TG analysis, NMR, FTIR, and atomic absorption spectrophotometry, electronic spectra, magnetic moments and conductivity measurements. The mole ratio of the ligands to the metal ion was 1:1 with tridentate bonding behaviors of the coordinating ligands with the metal ions.

\section{Keywords}

Cefotaxime, Schiff Bases, Metal Complexes, Antibacterial Activity

\section{Introduction}

Research work on the synthesis of Schiff base derivatives of cephalosporins antibiotics is still limited compared "Corresponding author.

How to cite this paper: Abdulghani, A.J. and Hussain, R.K. (2015) Synthesis and Characterization of Schiff Base Metal Complexes Derived from Cefotaxime with $1 \mathrm{H}$-indole-2,3-dione (Isatin) and 4-N,N-dimethyl-aminobenzaldehyde. Open Journal of Inorganic Chemistry, 5, 83-101. http://dx.doi.org/10.4236/ojic.2015.54010 
with other organic compounds. This is attributed to the presence of a variety of interacting groups in the skeleton of these molecules which results in low yields [1]-[5]. Complexation of these Schiff base derivatives with several metal ions showed the capability of forming mono-, di- and polynuclear metal complexes in which they behaved as monodentate, bidentate or tridentate ligands depending on the positions and number of electron donating groups [1] [2] [4] [5]. Cefotaxime sodium (sodium(6R,7R)-3-(acetoxymethyl)-7-(2-(2-aminothiazol-4-yl)2-(methoxyimino)acetamido)-8-oxo-5-thia-1-azabicyclo [4.2.0]oct-2-ene-2-carboxylate) is a third generation cephalosporin antibiotic having a broad activity against gram positive cocci (not enterococcus), gram negative bacteria (not Pseudomonas), and high resistance against the action of $\beta$-lactamases, as well as low index of side effects [6]. Isatin ( $1 \mathrm{H}$-Indole-2,3-dione) is one of the most promising class of aromatic heterocyclic organic compounds having many interesting activity profiles and well-tolerated in human subjects [7]. Isatin and its Schiff base derivatives showed a variety of biological and pharmacological activities as antimicrobial, antidepressant, anti-HIV, cytotoxicity, anlagesic, antileshmanial, anticonvulsant, insecticides, fungicides, anticancer, tuberculostatic, and anti-inflammatory [7]-[12]. This work studies the synthesis and characterization of new metal complexes of two Schiff base ligands derived from the condensation reaction of cefotaxime with $1 \mathrm{H}$-Indole-2, 3-dione (isatin) $\left(\mathrm{L}_{\mathrm{I}}\right)$ and p-dimethylaminobenzaldehyde (N,N-DMAB) $\left(\mathrm{L}_{\mathrm{II}}\right)$ (Scheme 1 ) and studies the coordination behavior of the two ligands with $\mathrm{Co}(\mathrm{II}), \mathrm{Ni}(\mathrm{II}), \mathrm{Cu}(\mathrm{II}), \mathrm{Cd}(\mathrm{II}), \mathrm{Pd}(\mathrm{II})$ and $\mathrm{Pt}(\mathrm{IV})$ ions.

\section{Experimental}

\subsection{Materials and Methods}

All chemicals were of analytical grades and were used as received from suppliers without further purification. Because of limited solubility of palladium (II) chloride, the salt was converted first to the complex dichlorobis (benzonitrile) palladium (II) $\left[\mathrm{PdCl}_{2}\left(\mathrm{PhCN}_{2}\right.\right.$ ] prior to use following the method reported by Rochow [13]. Purity of products was detected by TLC techniques using a mixture of acetone: chloroform (1:1 and 1:2 v/v), ether: chloroform (1:1 v/v), ethanol: chloroform (1:2) v/v) and chloroform only as eluents, and iodine chamber for spot location.

\subsection{Instruments}

Melting points (uncorrected) were determined on a Gallenkamp M.F.B 600 - 010f melting point apparatus. Fourier Transform Infrared (FTIR) spectra were obtained using a SHIMADZUE FT-IR 8400S Fourier transforms,

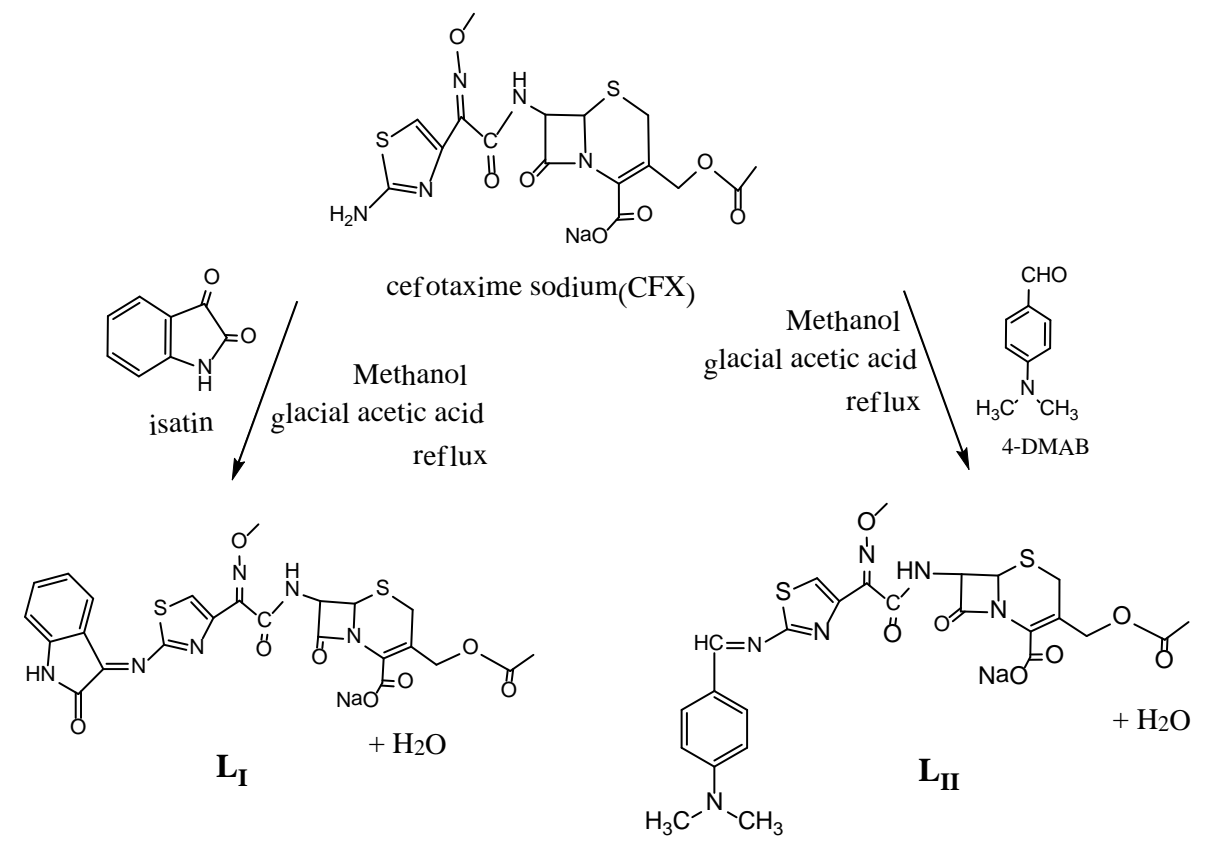

Scheme 1. Synthetic route of the two Schiff base derivatives of cefotaxime. 
within the wavenumber region between 4000 and $400 \mathrm{~cm}^{-1}$ using $\mathrm{KBr}$ disc and 4000 and $200 \mathrm{~cm}^{-1}$ using CsI disc. Electronic spectra for compounds in the (UV-Visible) region $(200$ - 1100) nm were recorded using a SHIMADZUE 1800 Double Beam UV-Visible spectrophotometer. Elemental microanalysis was performed on Eurovector EA 3000A. ${ }^{1} \mathrm{H}-\mathrm{NMR}$ and ${ }^{13} \mathrm{C}-\mathrm{NMR}$ spectra were performed by using a Bruker Ultra Sheild 300 MHz NMR, Al al-Bayt University (Jordan) and Delta A2 NMR JMN-ECS 400 MHz Manchester Metropolitan University. Thermal analyses (TG and DTG) of samples were performed under helium and nitrogen atmospheres at heating range of $\left(25^{\circ} \mathrm{C}-900^{\circ} \mathrm{C}\right)$ and $\left(25^{\circ} \mathrm{C}-800^{\circ} \mathrm{C}\right)$ respectively and heating rate of $20^{\circ} \mathrm{C} / \mathrm{min}$. by using Perkin Elmer TGA 4000. Molar conductivity measurements $\left(\mathrm{S} \cdot \mathrm{mol}^{-1} \cdot \mathrm{cm}^{2}\right)$ for metal complexes $(10-3 \mathrm{M})$ in DMF, DMSO at room temperature were carried out by using LASSCO Digital Conductivity Meter. Magnetic moments (eff. B.M) for the prepared complexes in the solid state at room temperature were measured according to Faraday's method by using Bruker Magnet B.M-6, Atomic Absorption measurements were performed using BUCK Scientific model 210 VGP USA Atomic Absorption Spectrophotometer.

\subsection{Synthesis of Ligands}

Synthesis of [sodium 3-(acetoxymethyl)-7-((Z)-2-(methoxyimino)-2-(2-((E)-2-oxoindolin-3-ylideneamino) thiazol-4-yl) acetamido)-8-oxo-5-thia-1-azabicyclo [4.2.0]oct-2-ene-2-carboxylate]. (0.5) Methanol $\left(L_{I}\right)$ :

To a stirred solution of isatin $(0.308 \mathrm{~g}, 2 \mathrm{~m} \cdot \mathrm{mole})$ in hot methanol $(10 \mathrm{ml})$ was added $(1 \mathrm{~g}, 2 \mathrm{~m} \cdot \mathrm{mole})$ of cefotaxime sodium salt in hot methanol $(15 \mathrm{ml})$ followed by $2 \mathrm{ml}$ of glacial acetic acid. The reaction mixture was heated under reflux for $6 \mathrm{~h}$ with continuous stirring. The color of solution was changed from orange to brown followed by the formation of a brown precipitate. The product was filtered, washed with hot mixture methanol: water (v: v) (80:20) \% followed by cold methanol and ether and vacuum dried.

Synthesis of [sodium 3-(acetoxymethyl)-7-((2Z)-2-(2-(4-dimethylamino) benzylideneamino) thiazol-4-yl)-2(methoxyimino) acetamido)-8-oxo-5-thia-1-azabicyclo[4.2.0]oct-2-ene-2-carbo-xylate]. (0.5) Methanol $\left(L_{I I}\right)$ :

This ligand was previously prepared by A. H. kshash in ethanol at $\mathrm{pH} 4$ [4]. In this work we prepared the ligand adopting a different procedure. A hot solution of 4-dimethylamino benzaldehyde (DMAB) (0.312 g, 2 mmol) in methanol $(3 \mathrm{ml})$ was added to a hot stirred solution of cefotaxime sodium salt $(1 \mathrm{~g}, 2 \mathrm{~m} \cdot \mathrm{mol})$ in the same solvent $(15 \mathrm{ml})$. Then glacial acetic acid was added $(1.5 \mathrm{ml})$ and the mixture was heated under reflux for 3 $\mathrm{h}$ to achieve complete precipitation. An olive green precipitate was formed. The product was filtered, washed several times with a hot mixture of methanol-water followed by cold methanol and ether and vacuum dried.

\subsection{Synthesis of Metal Complexes}

To a stirred solution of each ligand $(0.2 \mathrm{~g}, 0.33 \mathrm{~m} \cdot \mathrm{mol})$ in a mixture of ethanol-water (80:20)\% (3 ml) heated to boiling point was added an alcoholic solution of the metal salts: $\mathrm{CoCl}_{2} \cdot 6 \mathrm{H}_{2} \mathrm{O}, \mathrm{NiCl}_{2} \cdot 6 \mathrm{H}_{2} \mathrm{O}, \mathrm{CuCl}_{2} \cdot 2 \mathrm{H}_{2} \mathrm{O}$, $\mathrm{CdCl}_{2} \cdot 2 \mathrm{H}_{2} \mathrm{O}$, $\left[\mathrm{PdCl}_{2}\left(\mathrm{PhCN}_{2}\right.\right.$ ] and $\mathrm{K}_{2} \mathrm{PtCl}_{6}(0.039 \mathrm{~g}, 0.039 \mathrm{~g}, 0.028 \mathrm{~g}, 0.036 \mathrm{~g}, 0.029 \mathrm{~g}$ and $0.0804 \mathrm{~g}$ respectively, $0.16 \mathrm{~m} \cdot \mathrm{mol})$ with continuous stirring. Immediate precipitation of metal complexes $\left(\mathrm{C}_{1}-\mathrm{C}_{6}\right.$ respectively for $\mathrm{L}_{\mathrm{I}}$ complexes and $\mathrm{C}_{7}-\mathrm{C}_{12}$ for $\mathrm{L}_{\mathrm{II}}$ complexes) was observed. Reflux was continued for $1 \mathrm{~h}$ for complete precipitation. The products were filtered off, washed with hot EtOH: $\mathrm{H}_{2} \mathrm{O}$ followed by ether and vacuum dried.

\section{Results and Discussion}

\subsection{Physical Properties and Elemental Analyses}

The physical properties and results obtained from C.H.N. analyses and metal contents of the prepared compounds are described in Table 1. The analytical data were almost agreeable with calculated values with some deviations attributed to incomplete combustion or technical errors. The molecular formula of the ligands and their metal complexes were suggested according to these data together with those obtained from spectral and thermal analyses as well as conductivity and magnetic susceptibility of metal complexes.

\section{2. ${ }^{1} \mathrm{H}-\mathrm{NMR}$ Spectra}

The ${ }^{1}$ HNMR spectrum of $\mathrm{L}_{\mathrm{I}}$ (Figure 1) displayed a single peak appeared at $\delta(9.8)$ and a multiplet peak at $\delta$ (6.801 - 7.58) ppm which were assigned to chemical shifts of NH and aromatic protons of isatin moiety [14]-[16]. The signals observed at $\delta 4.833,4.66$ and 9.06 ppm were attributed to chemical shifts of $\mathrm{N}-\mathrm{CH}$ and $\mathrm{CO}-\mathrm{CH}$ 
Table 1. Physical properties and analytical data for $\mathrm{L}_{\mathrm{I}}, \mathrm{L}_{\mathrm{II}}$ ligands and their metal complexes.

\begin{tabular}{|c|c|c|c|c|c|c|c|c|c|}
\hline \multirow{2}{*}{ Symbol } & \multirow{2}{*}{ Color } & \multirow{2}{*}{$\begin{array}{l}\text { Decom Temp. } \\
\text { (m.p.) }{ }^{\circ} \mathrm{C}\end{array}$} & \multirow{2}{*}{ Yield \% } & \multicolumn{4}{|c|}{ \% Element Analysis Found (calculated) } & \multirow{2}{*}{$\begin{array}{c}\text { \% Metal } \\
\text { Found (calc.) }\end{array}$} & \multirow{2}{*}{$\begin{array}{l}\text { \% Chloride } \\
\text { Found (calc.) }\end{array}$} \\
\hline & & & & $\% \mathrm{C}$ & $\% \mathrm{H}$ & $\% \mathbf{N}$ & $\% \mathrm{~S}$ & & \\
\hline $\mathrm{L}_{\mathrm{I}}^{\mathrm{a}}$ & Yellow Brawn & 220 & 63.6 & $\begin{array}{c}47.45 \\
(47.23)\end{array}$ & $\begin{array}{c}3.23 \\
(3.37)\end{array}$ & $\begin{array}{c}13.32 \\
(13.49)\end{array}$ & $\begin{array}{c}10.01 \\
(10.28)\end{array}$ & - & - \\
\hline $\mathrm{C}_{1} \mathrm{Co}(\mathrm{II})$ & Green & $>260$ & 50 & $\begin{array}{c}40.56 \\
(40.75)\end{array}$ & $\begin{array}{l}2.61 \\
(3.5)\end{array}$ & $\begin{array}{l}11.56 \\
(11.39)\end{array}$ & $\begin{array}{c}8.67 \\
(8.68)\end{array}$ & $\begin{array}{l}8.12 \\
(8.0)\end{array}$ & $\begin{array}{c}4.2 \\
(4.8)\end{array}$ \\
\hline $\mathrm{C}_{2} \mathrm{Ni}(\mathrm{II})$ & Off White & 220 & $22 \%$ & $\begin{array}{c}40.3 \\
(40.7)\end{array}$ & $\begin{array}{l}2.98 \\
(3.5)\end{array}$ & $\begin{array}{l}11.55 \\
(11.4)\end{array}$ & $\begin{array}{l}8.89 \\
(8.7)\end{array}$ & $\begin{array}{c}8.22 \\
(7.97)\end{array}$ & $\begin{array}{l}4.51 \\
(4.8)\end{array}$ \\
\hline $\mathrm{C}_{3} \mathrm{Cu}(\mathrm{II})$ & Light Green & 175 & 33.17 & $\begin{array}{c}40.2 \\
(40.4)\end{array}$ & $\begin{array}{c}2.8 \\
(3.5)\end{array}$ & $\begin{array}{l}11.37 \\
(11.3)\end{array}$ & $\begin{array}{l}8.66 \\
(8.6)\end{array}$ & $\begin{array}{c}8.93 \\
(8.57)\end{array}$ & $\begin{array}{c}4.22 \\
(4.79)\end{array}$ \\
\hline $\mathrm{C}_{4} \mathrm{Cd}(\mathrm{II})$ & Brown & 200 & 21.4 & $\begin{array}{c}38.88 \\
(39.09)\end{array}$ & $\begin{array}{c}4.62 \\
(4.07)\end{array}$ & $\begin{array}{l}10.33 \\
(9.77)\end{array}$ & $\begin{array}{l}7.76 \\
(7.46)\end{array}$ & $\begin{array}{c}12.9 \\
(13.08)\end{array}$ & $\begin{array}{c}4.3 \\
(4.13)\end{array}$ \\
\hline $\mathrm{C}_{5} \mathrm{Pd}(\mathrm{II})$ & Pale Yellow & $>260$ & 72.9 & $\begin{array}{l}38.05 \\
(37.8)\end{array}$ & $\begin{array}{c}4.8 \\
(3.8)\end{array}$ & $\begin{array}{c}10.63 \\
(10.18)\end{array}$ & $\begin{array}{c}7.89 \\
(7.75)\end{array}$ & $\begin{array}{l}13.21 \\
(12.9)\end{array}$ & $\begin{array}{c}4.6 \\
(4.3)\end{array}$ \\
\hline $\mathrm{C}_{6} \mathrm{Pt}(\mathrm{IV})$ & Light Brown & $>260$ & 58.33 & $\begin{array}{l}33.88 \\
(33.5)\end{array}$ & $\begin{array}{l}2.86 \\
(2.68)\end{array}$ & $\begin{array}{c}9.8 \\
(9.02)\end{array}$ & $\begin{array}{c}7.2 \\
(6.87)\end{array}$ & $\begin{array}{l}20.62 \\
(20.94)\end{array}$ & $\begin{array}{c}10.6 \\
(11.44)\end{array}$ \\
\hline $\mathrm{L}_{\mathrm{II}}^{\mathrm{b}}$ & Yellow Green & 210 & 58.3 & $\begin{array}{c}50.0 \\
(49.0)\end{array}$ & $\begin{array}{l}4.32 \\
(4.3)\end{array}$ & $\begin{array}{c}13.45 \\
(13.45)\end{array}$ & $\begin{array}{l}10.18 \\
(10.25)\end{array}$ & - & - \\
\hline $\mathrm{C}_{7} \mathrm{Co}(\mathrm{II})$ & Green & $>260$ & 34 & $\begin{array}{c}42.2 \\
(42.2)\end{array}$ & $\begin{array}{l}3.75 \\
(4.3)\end{array}$ & $\begin{array}{c}8.4 \\
(8.6)\end{array}$ & $\begin{array}{c}11.1 \\
(11.4)\end{array}$ & $\begin{array}{c}7.62 \\
(7.97)\end{array}$ & $\begin{array}{c}4.2 \\
(4.8)\end{array}$ \\
\hline $\mathrm{C}_{8} \mathrm{Ni}(\mathrm{II})$ & Light Green & 240 & 17 & $\begin{array}{c}42.0 \\
(42.2)\end{array}$ & $\begin{array}{l}3.87 \\
(4.3)\end{array}$ & $\begin{array}{c}11.32 \\
(11.36)\end{array}$ & $\begin{array}{c}8.92 \\
(8.69)\end{array}$ & $\begin{array}{c}7.73 \\
(7.94)\end{array}$ & $\begin{array}{c}4.4 \\
(4.8)\end{array}$ \\
\hline $\mathrm{C}_{9} \mathrm{Cu}(\mathrm{II})$ & Green Oil & 210 & 50.6 & $\begin{array}{c}41.8 \\
(41.9)\end{array}$ & $\begin{array}{l}3.76 \\
(3.4)\end{array}$ & $\begin{array}{c}11.35 \\
(11.29)\end{array}$ & $\begin{array}{l}9.07 \\
(8.6)\end{array}$ & $\begin{array}{l}8.61 \\
(8.5)\end{array}$ & $\begin{array}{c}4.9 \\
(4.77)\end{array}$ \\
\hline $\mathrm{C}_{10} \mathrm{Cd}(\mathrm{II})$ & Off White & 250 & 67.24 & $\begin{array}{l}39.41 \\
(39.7)\end{array}$ & $\begin{array}{c}3.75 \\
4.29)(\end{array}$ & $\begin{array}{l}10.48 \\
(10.3)\end{array}$ & $\begin{array}{c}8.01 \\
(7.85)\end{array}$ & $\begin{array}{c}13.80 \\
(13.78)\end{array}$ & $\begin{array}{c}4.21 \\
(4.35)\end{array}$ \\
\hline $\mathrm{C}_{11} \mathrm{Pd}(\mathrm{II})$ & Brawn & 200 & 28.57 & $\begin{array}{c}40.36 \\
(40.96)\end{array}$ & $\begin{array}{c}3.71 \\
(4.16)\end{array}$ & $\begin{array}{l}10.95 \\
(10.6)\end{array}$ & $\begin{array}{l}8.019 \\
(8.08)\end{array}$ & $\begin{array}{c}13.22 \\
(13.44)\end{array}$ & $\begin{array}{l}4.62 \\
(4.48)\end{array}$ \\
\hline $\mathrm{C}_{12} \mathrm{Pt}(\mathrm{IV})$ & Brawn & 210 & 46.218 & $\begin{array}{c}33.5 \\
(33.6)\end{array}$ & $\begin{array}{c}3.13 \\
(3.23)\end{array}$ & $\begin{array}{l}9.09 \\
(9.05)\end{array}$ & $\begin{array}{l}7.008 \\
(6.89)\end{array}$ & $\begin{array}{c}20.6 \\
(21.02)\end{array}$ & $\begin{array}{c}10.9 \\
(11.47)\end{array}$ \\
\hline
\end{tabular}

The Na\%, found (cal.) of $\mathrm{L}_{\mathrm{I}}^{\mathrm{a}}=3.88(3.7) \%, \mathrm{~L}_{\mathrm{II}}^{\mathrm{b}}=3.8(3.7) \%$.

protons on the beta-lactam ring [17] and of amide NH proton [3] [18] respectively. The peak appeared at $\delta$ (3.7) ppm was attributed to the chemical shift of S- $\mathrm{CH}_{2}$ protons on the dihydrothiazine ring [18]. The signals related to methyl protons were observed at the range (2.3 - 3.233) ppm [19] [20]. The signal related to the thiazole ring proton appeared at $\delta 8.79 \mathrm{ppm}$ [3] [16] [19]. No signal was observed in the spectrum related to the free amino group of cefotaxime which support the formation of the Schiff base ligand. The ${ }^{1} \mathrm{H}$ NMR spectrum of the Ni(II) complex $\left(\mathbf{C}_{2}\right)$ in DMSO (Figure 2), displayed signals located at $\delta$ (7.3 - 6.90), 4.253, 4.317 and (3.35 - 1.2) ppm and were attributed to chemical shifts of aromatic protons of indole ring moiety [14]-[16], CO-CH and N-CH protons on the beta-lactam ring [17] [18] and methyl protons [17] [19] [20] respectively. The ${ }^{1}$ HNMR spectrum of $\mathrm{L}_{\mathrm{II}}$ (Figure 3) exhibited the signals related to the NH proton of amide group [3] [15] [18], azomethine proton [3] [16] [21], thiazole ring proton [3] [16] [18] and aromatic protons [16] [21] appeared at $\delta 9.667, \delta 9.05$ (s), $8.2 \mathrm{ppm}$ and $7.841-6.782(\mathrm{~m})$ respectively. The doublet signal observed at $\delta(4.87)$ and (4.625) ppm were assigned to N-CH [16] [17], and CO-CH [15] [18] protons in the $\beta$-lactam ring. Chemical shifts of S- $\mathrm{CH}_{2}$ protons, aliphatic $\mathrm{CH}_{2}$, and methyl protons were observed at $\delta$ (3.048, 3.813 [16] [18] and (1.072 - 3.166) [16] [19] [22] ppm respectively. No signal related to chemical shift of $\mathrm{NH}_{2}$ group was observed, which confirms the formation of the Schiff base ligand [20]. The ${ }^{1} \mathrm{H}-\mathrm{NMR}$ spectrum of the Co (II) complex of $\mathrm{L}_{\mathrm{II}}\left(\mathrm{C}_{7}\right)$ in DMSO (Figure 4(a), Figure 4(b)) exhibited the signals assignable to the proton of amide group, azomethine group and aromatic protons which appeared at $\delta 10.45$ [15] [17], 8.036 [3] [23] and 6.0 - 7.016) [15] ppm respectively. The spectrum also showed two peaks at $\delta$ (5.264) and $5.166 \mathrm{ppm}$ which were attributed to $\mathrm{N}-\mathrm{CH}$ and $\mathrm{CO}-\mathrm{CH}$ protons in the beta lactam ring respectively [15] [18]. Peaks assigned to chemical shifts of aliphatic $\mathrm{CH}_{2}$ protons, $\mathrm{CH}_{2}$ protons of dihydrothiazine ring and methyl protons were observed at $\delta 3.813$ [20], 3.55 [18] and (2.469 - 3.9) [16] [20] 


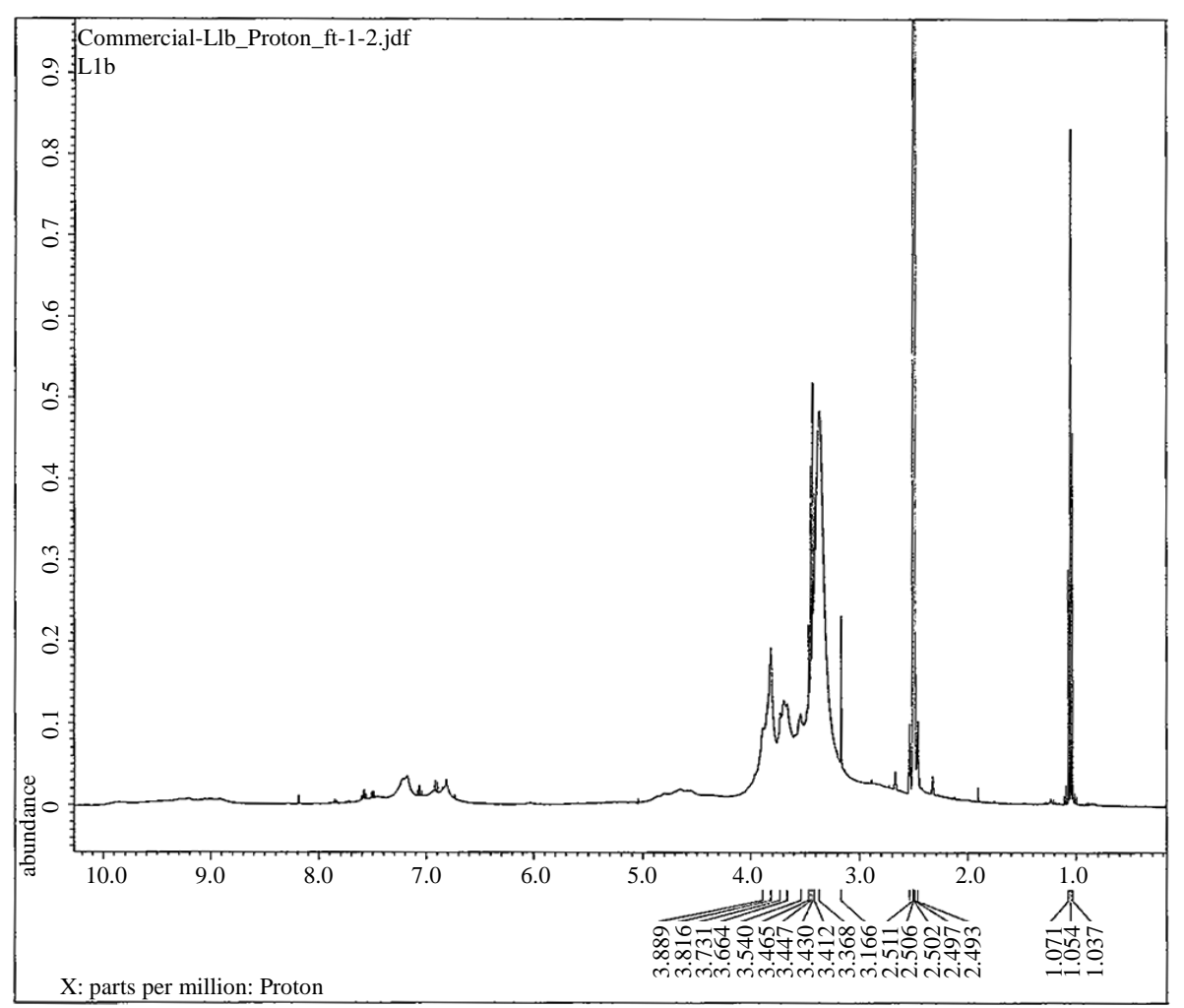

(a)

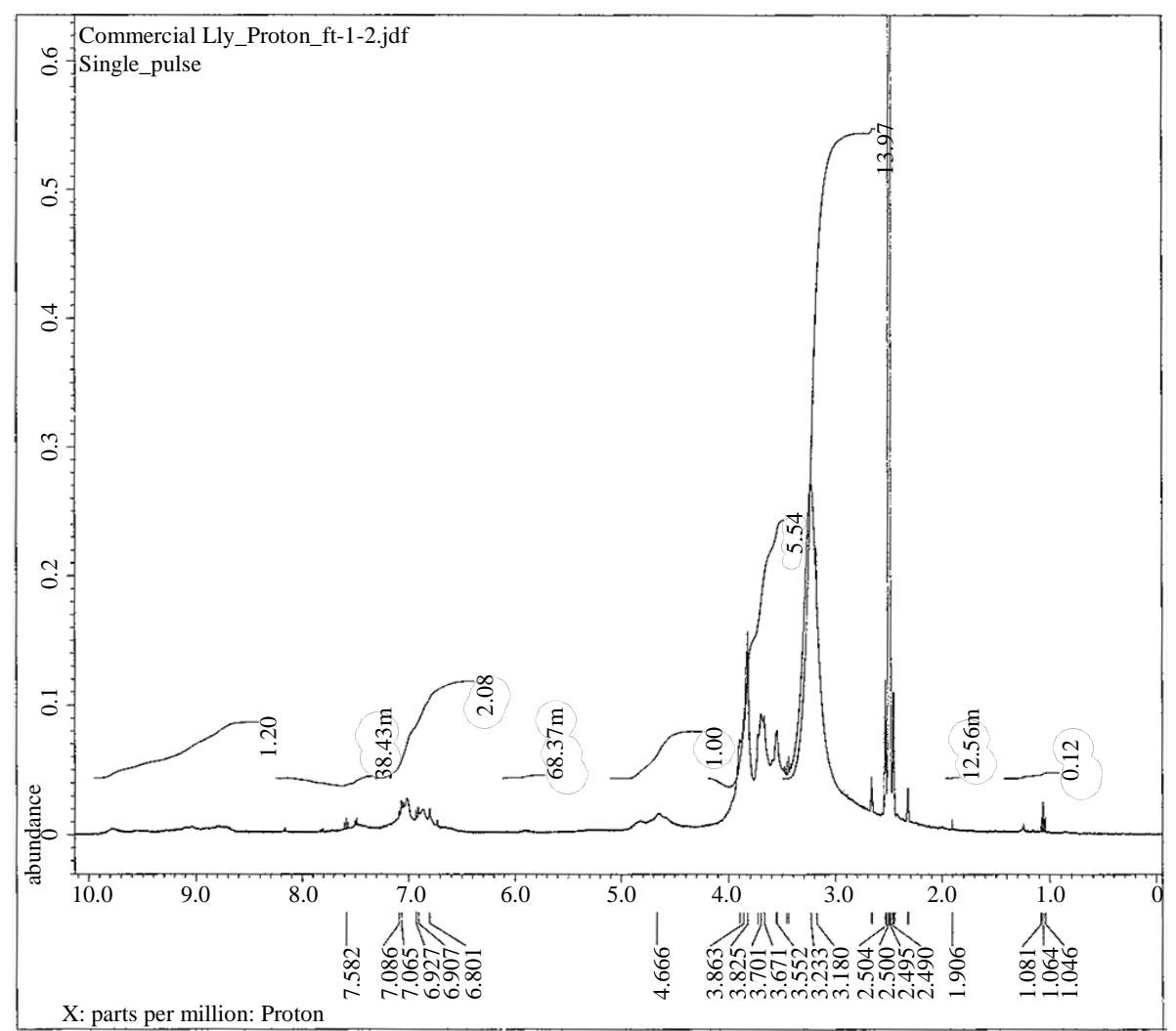

(b)

Figure 1. ${ }^{1} \mathrm{HNMR}$ spectrum of $\mathrm{L}_{\mathrm{I}}$ (a) before drying and (b) after vacuum drying. 

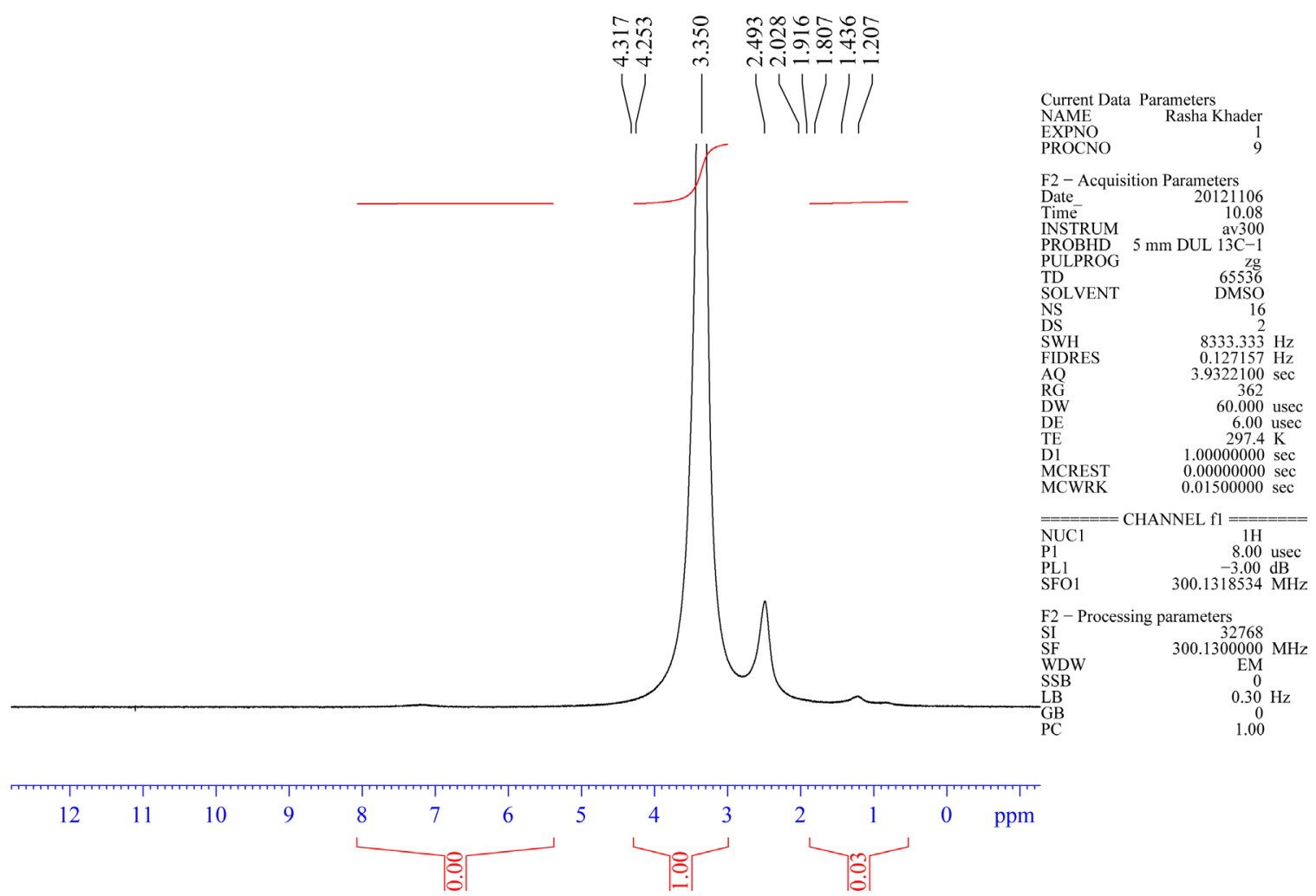

(a)
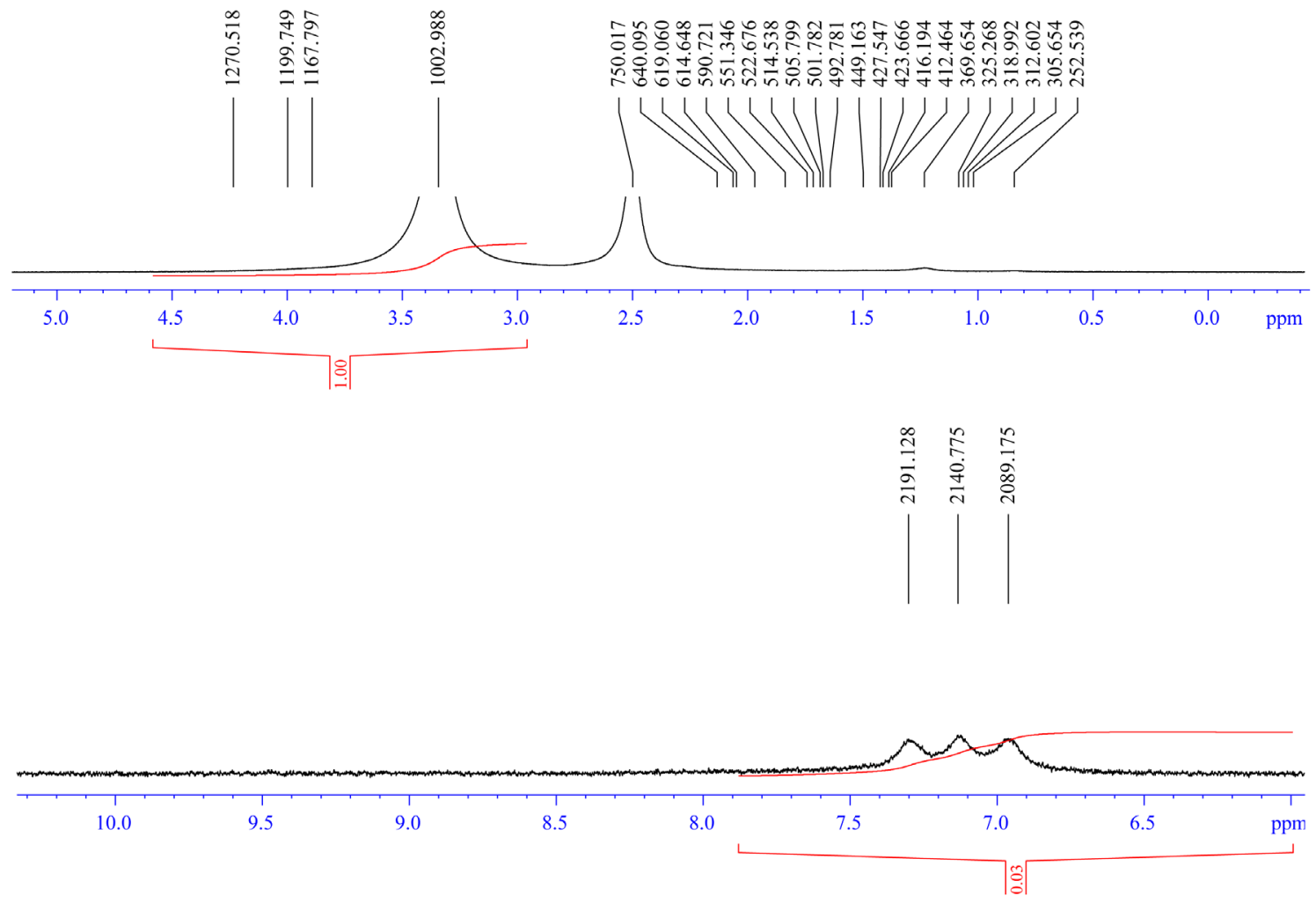

(b)

Figure 2. Full and extended ${ }^{1} \mathrm{HNMR}$ spectrum of $\mathrm{NiL}_{\mathrm{I}}$ complex $\left(\mathrm{C}_{2}\right)$. 


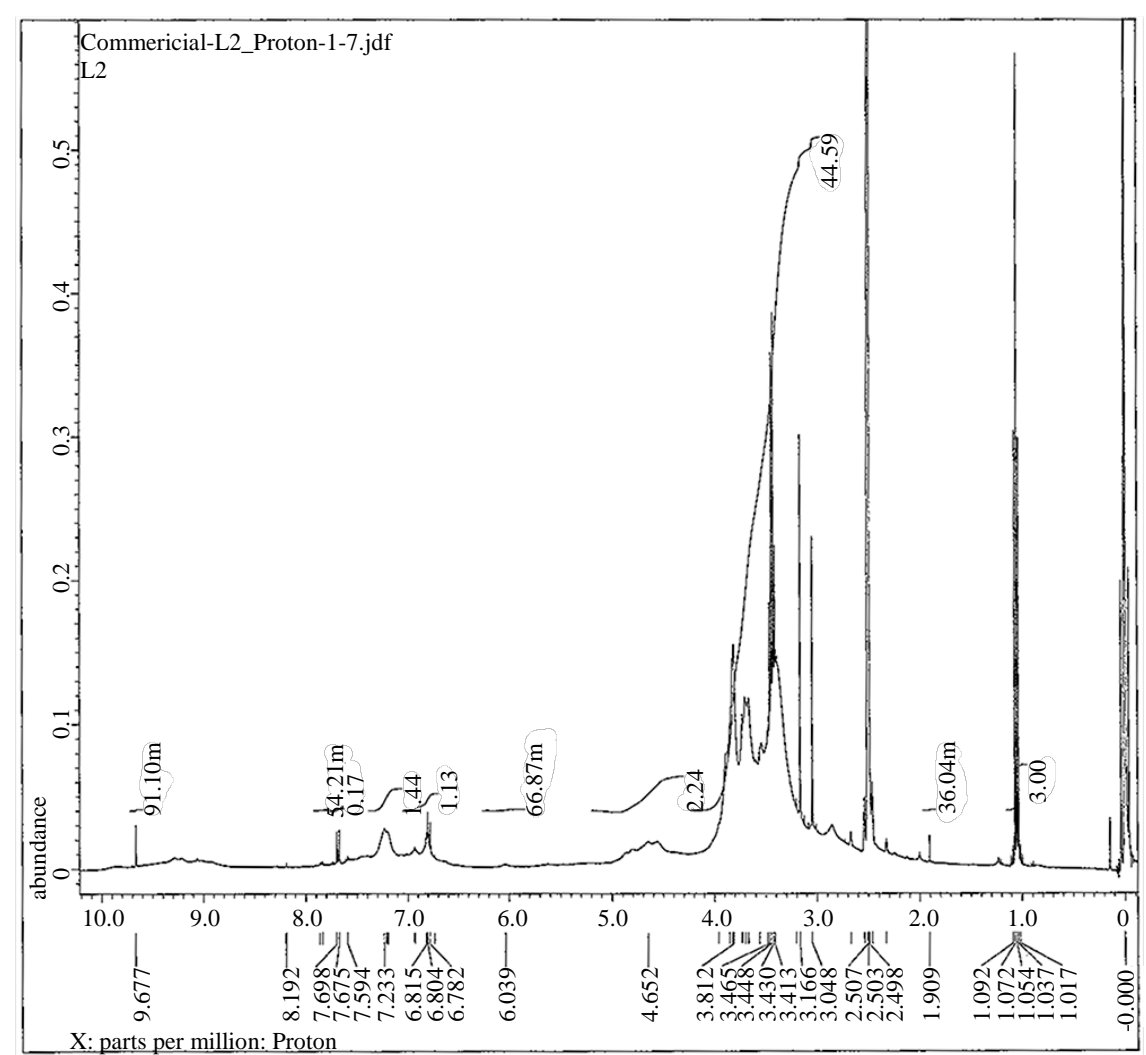

(a)

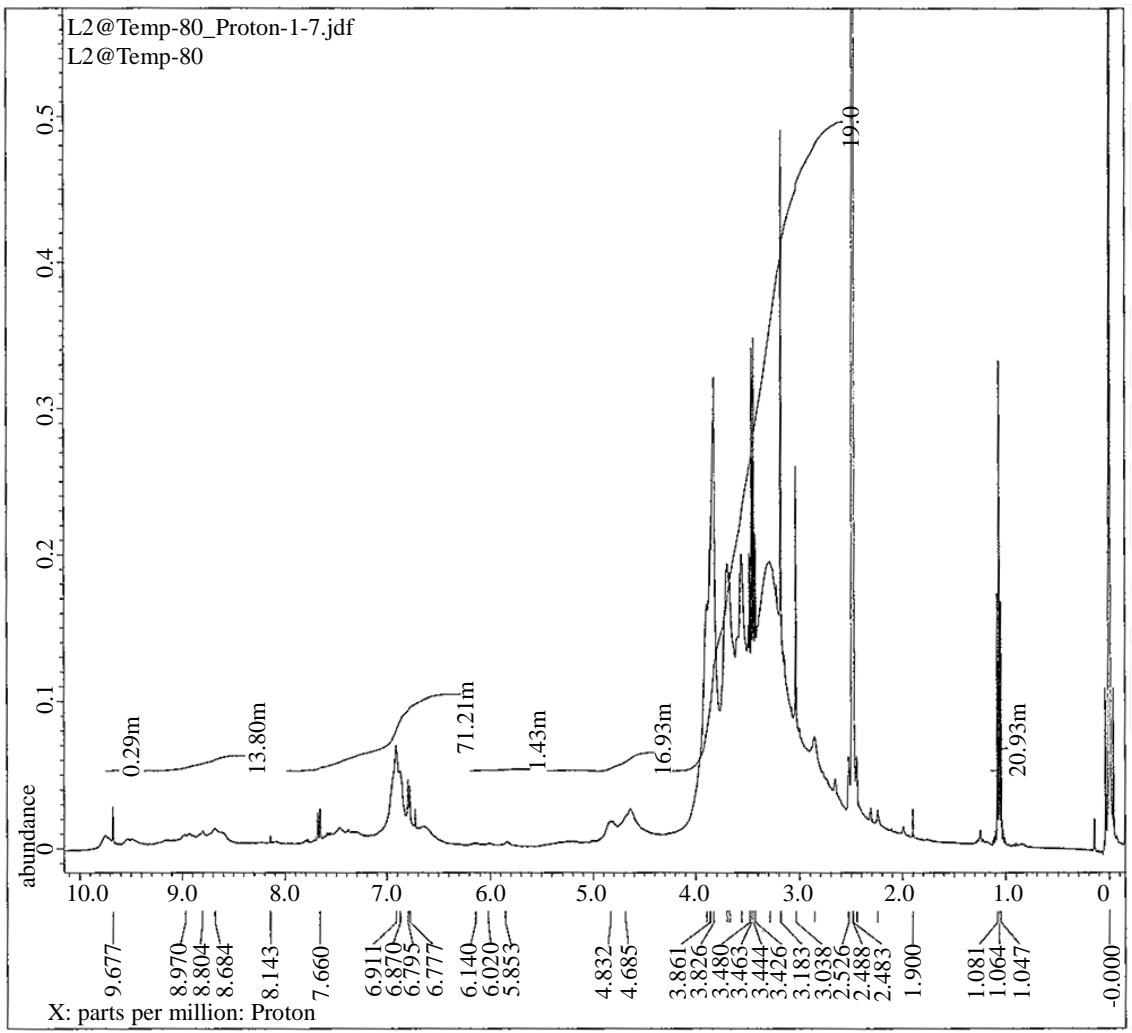

(b)

Figure $3 .{ }^{1} \mathrm{HNMR}$ spectrum of $\mathrm{L}_{\mathrm{II}}$ (a) before and (b) after vacuum drying. 

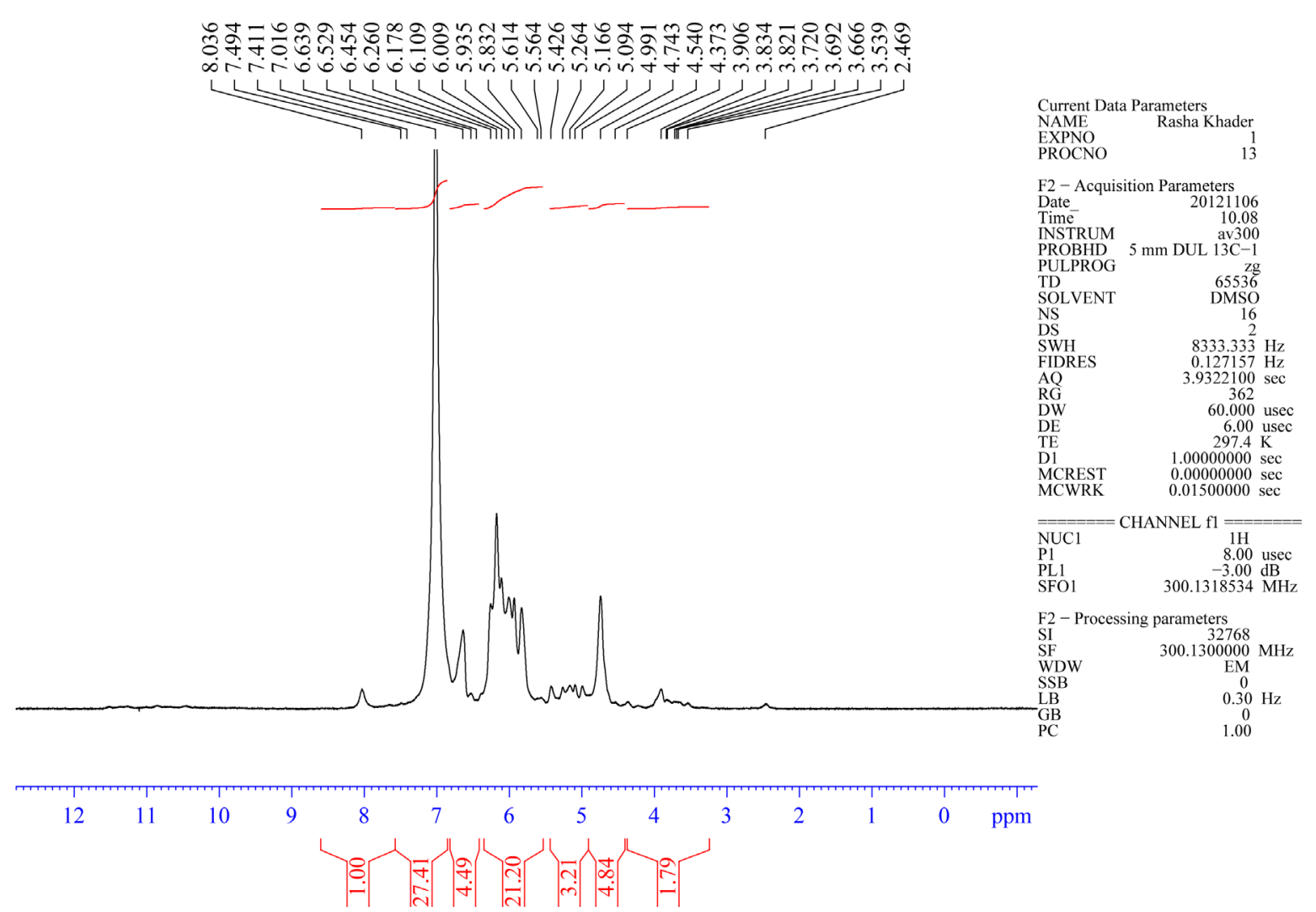

(a)
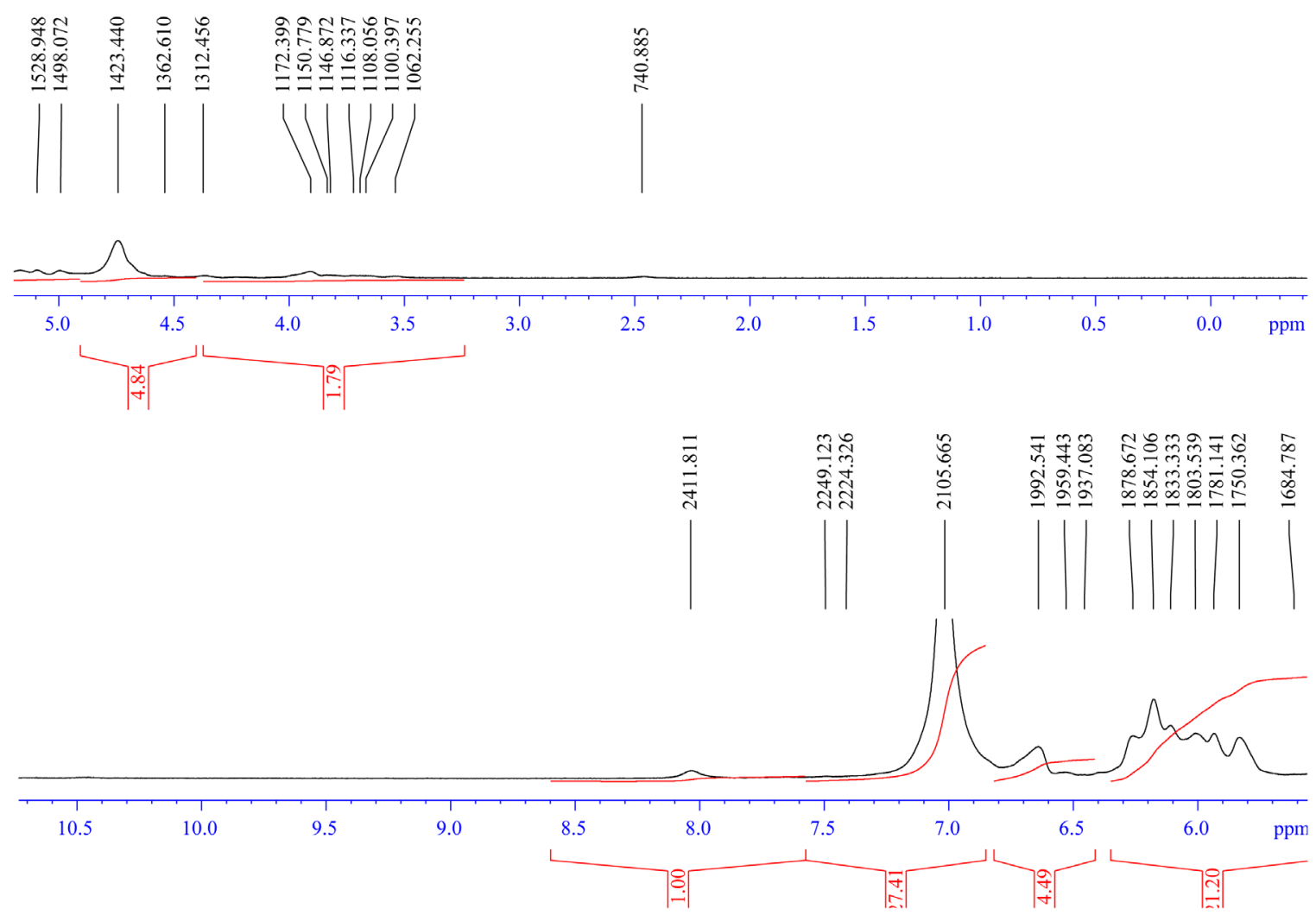

(b) 

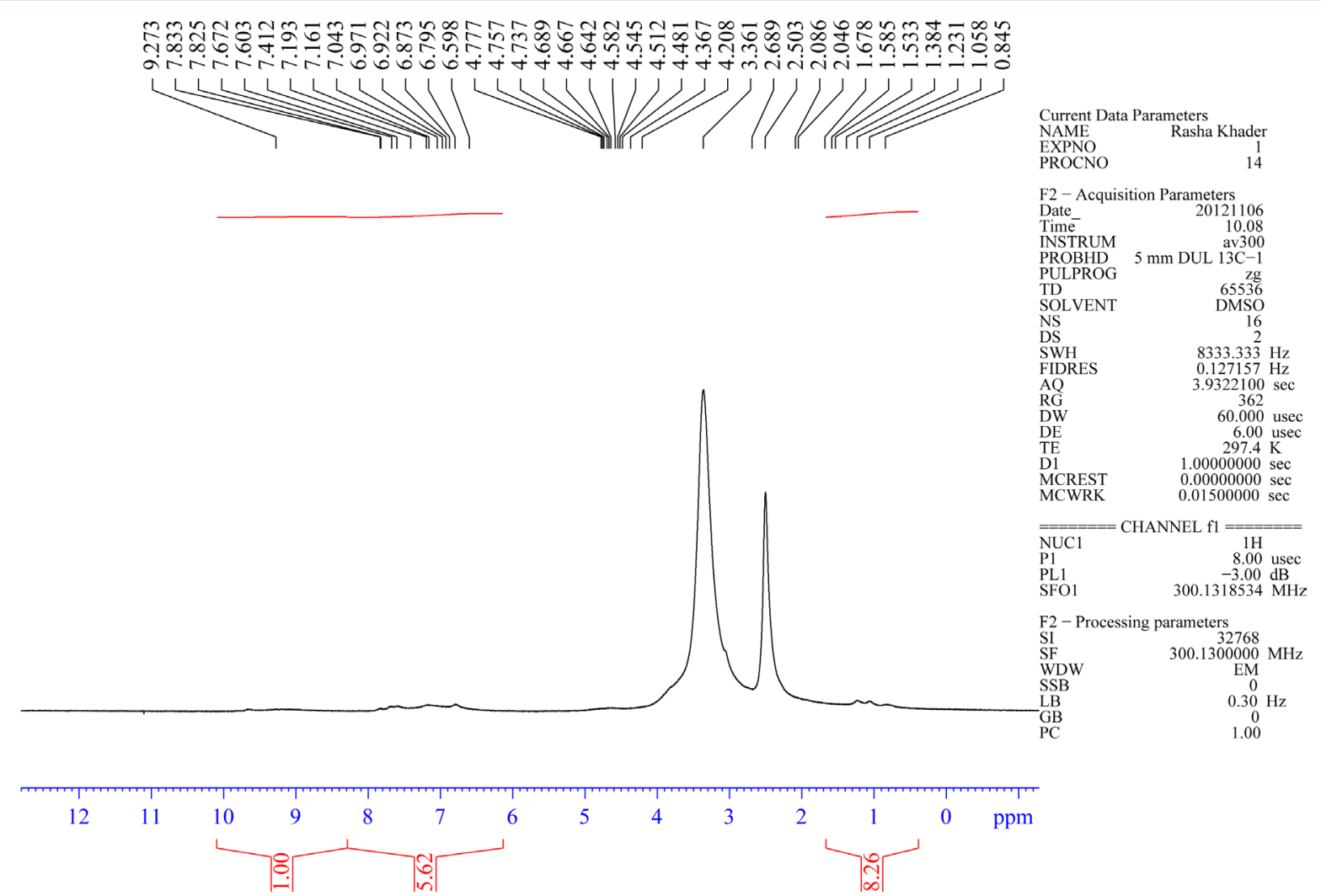

(c)
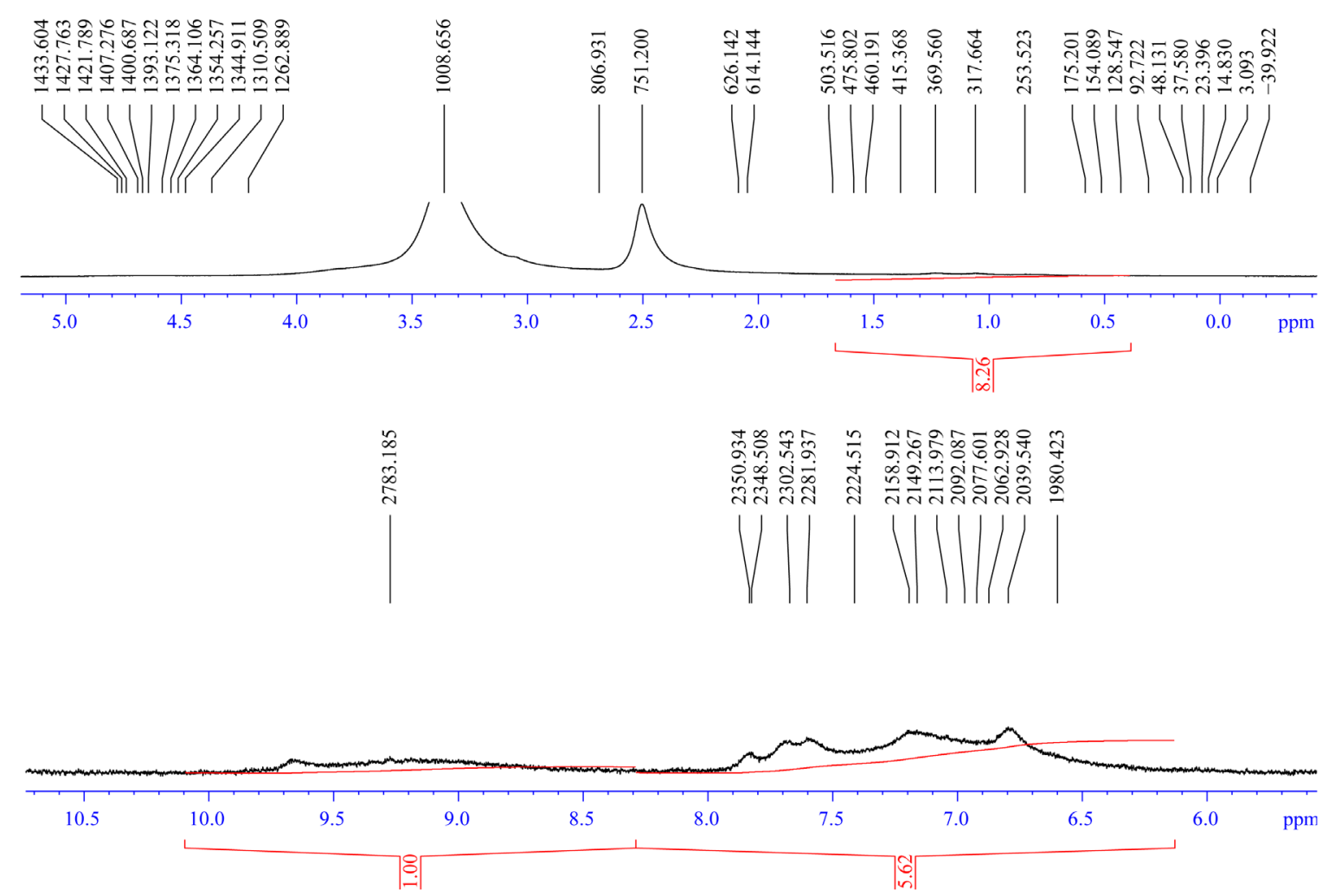

(d)

Figure 4. Full and extended ${ }^{1}$ HNMR spectra of $\mathrm{CoL}_{I I}\left(\mathrm{C}_{7}\right)(\mathrm{a})$ and $(\mathrm{b})$ and $\mathrm{CuL}_{\mathrm{II}}\left(\mathrm{C}_{9}\right)(\mathrm{c})$ and $(\mathrm{d})$. 
[22] ppm respectively. The ${ }^{1} \mathrm{HNMR}$ spectrum of the $\mathrm{Cu}$ (II) complex (C9) (Figure 4(c), Figure 4(d)) displayed signals appeared at $\delta 9.65,7.833-6.598,4.77,4.208$ and $0.845-3.361 \mathrm{ppm}$ which were attributed to the protons of amide group [3] [15] [18], aromatic protons [17] [24], NCH and COCH protons of $\beta$-lactam ring [16]-[18] and methyl protons [17] [19] [20] respectively. The new peaks observed at $\delta 2.086,2.046 \mathrm{ppm}$ may be assigned to coordinated water molecules [15].

\subsection{Infrared Spectra}

Table 2 and Table 3 describe respectively the important vibrational modes of $\mathrm{L}_{\mathrm{I}}, \mathrm{L}_{\mathrm{II}}$ and their metal complexes. Both $\mathrm{L}_{\mathrm{I}}$ and $\mathrm{L}_{\mathrm{II}}$ have several potential donor atoms but, due to steric constraints, the ligands can provide a maximum of three donor atoms to any one metal center [18]. The infrared spectra of the two ligands exhibited the absence of absorption bands at $\left(3348,3252 \mathrm{~cm}^{-1}\right)$ corresponding to stretching modes of $\mathrm{NH}_{2}$ group of cefotaxime and at 1728, and $1664 \mathrm{~cm}^{-1}$ assigned to (C-3) carbonyl of isatin [25] [26] and C=O group of N, N-DMAB[5] which refers to the formation of the Schiff base ligands by condensation reaction between both isatin and $\mathrm{N}$, $\mathrm{N}$-DMAB with the antibiotic to form the azomethine $\mathrm{CH}=\mathrm{N}$ linkage. This was confirmed by the appearance of new bands at $v 1636$ and $1643 \mathrm{~cm}^{-1}$ respectively assignable to $v(\mathrm{C}=\mathrm{N}-)$ of azomethine group [1]-[5]. A broad band was observed around $3565 \mathrm{~cm}^{-1}$ and $3418 \mathrm{~cm}^{-1}$ of the two ligands respectively attributed to vibrational modes of hydrogen bonded $\mathrm{O}-\mathrm{H}$ group of methanol solvent embedded in the crystal lattice structure of the

Table 2. Characteristic IR stretching vibrations $\left(\mathrm{cm}^{-1}\right)$ of $\mathrm{L}_{\mathrm{I}}$ and its metal complexes.

\begin{tabular}{|c|c|c|c|c|c|c|c|c|}
\hline Symbol & $\begin{array}{l}\text { NH of amide } \\
\text { (isatin) }\end{array}$ & $\begin{array}{c}\mathrm{C}=\mathrm{O} \\
\text { of C2-isatin }\end{array}$ & $\begin{array}{c}\text { C=O B-lactam } \\
\text { (Amide + ester) }\end{array}$ & $\mathrm{C}=\mathrm{N}$ & $\begin{array}{c}-\mathrm{COO} \\
\text { Asym. (sym) }\end{array}$ & $\begin{array}{c}\mathrm{H}_{2} \mathbf{O} \\
\text { Lattice (coordinate) }\end{array}$ & $\begin{array}{c}\mathrm{M}-\mathrm{O}-\mathrm{COO} \\
\left(\mathrm{H}_{2} \mathrm{O}\right)\end{array}$ & $\begin{array}{l}\text { M-N } \\
\text { (M-Cl) }\end{array}$ \\
\hline $\mathrm{L}_{\mathrm{I}}$ & $\begin{array}{c}3255 \\
(3192)\end{array}$ & 1692 & $\begin{array}{l}1740 \\
(1659)\end{array}$ & 1636 & $\begin{array}{c}1568 \\
(1367)\end{array}$ & - & - & - \\
\hline $\mathrm{C}_{2} \mathrm{Ni}(\mathrm{II})$ & $\begin{array}{c}3252 \\
(3194)\end{array}$ & 1694 & $\begin{array}{c}1726 \\
(1658)\end{array}$ & 1626 & $\begin{array}{c}1611 \\
(1385)\end{array}$ & $\begin{array}{c}3525 \\
(3370,806,768)\end{array}$ & $\begin{array}{c}493 \\
(462)\end{array}$ & $\begin{array}{c}424 \\
(336)\end{array}$ \\
\hline $\mathrm{C}_{1} \mathrm{Co}(\mathrm{II})$ & $\begin{array}{c}3253 \\
(3194)\end{array}$ & 1695 & $\begin{array}{c}1728 \\
(1659)\end{array}$ & 1625 & $\begin{array}{c}1625 \\
\text { (1385) overlap }\end{array}$ & $\begin{array}{c}3525 \\
(3370,806,752)\end{array}$ & $\begin{array}{c}509 \\
(486)\end{array}$ & $\begin{array}{c}420 \\
(370)\end{array}$ \\
\hline $\mathrm{C}_{3} \mathrm{Cu}(\mathrm{II})$ & $\begin{array}{c}3253 \\
(3193)\end{array}$ & 1693 & $\begin{array}{c}1725 \\
(1661)\end{array}$ & 1624 & $\begin{array}{c}1624 \\
\text { overlap (1377) }\end{array}$ & $\begin{array}{c}3525 \\
(3375,806,768)\end{array}$ & $\begin{array}{c}486 \\
(455)\end{array}$ & $\begin{array}{c}424 \\
(370)\end{array}$ \\
\hline $\mathrm{C}_{4} \mathrm{Cd}(\mathrm{II})$ & $\begin{array}{c}3257 \\
(3194)\end{array}$ & 1695 & $\begin{array}{c}1729 \\
(1655)\end{array}$ & 1624 & $\begin{array}{c}1578 \\
(1377)\end{array}$ & $\begin{array}{c}3520 \\
(3400,802,768)\end{array}$ & $\begin{array}{c}579 \\
(556)\end{array}$ & $\begin{array}{c}440 \\
(348)\end{array}$ \\
\hline $\mathrm{C}_{5} \mathrm{Pd}(\mathrm{II})$ & $\begin{array}{c}3255 \\
(3190)\end{array}$ & 1695 & $\begin{array}{c}1730 \\
(1658)\end{array}$ & 1628 & $\begin{array}{l}1557 \\
(1356)\end{array}$ & 3525 & $\begin{array}{c}553 \\
(536)\end{array}$ & $\begin{array}{c}417 \\
(336)\end{array}$ \\
\hline $\mathrm{C}_{6} \mathrm{Pt}(\mathrm{IV})$ & $\begin{array}{l}3258 \\
(3194)\end{array}$ & 1693 & $\begin{array}{c}1725 \\
(1659)\end{array}$ & 1626 & $\begin{array}{c}1626 \\
\text { overlap (1404) }\end{array}$ & 3464 & $\begin{array}{c}556 \\
(517)\end{array}$ & $\begin{array}{c}451 \\
(374)\end{array}$ \\
\hline
\end{tabular}

Table 3. Characteristic IR stretching vibrations $\left(\mathrm{cm}^{-1}\right)$ of $\mathrm{L}_{\mathrm{II}}$ and its metal complexes.

\begin{tabular}{|c|c|c|c|c|c|c|c|}
\hline Symbol & $\begin{array}{l}\mathrm{NH} \text { of } \\
\text { amide }\end{array}$ & $\begin{array}{c}\text { C=O B-lactam } \\
\text { (Amide + ester) }\end{array}$ & $C=N$ & $\begin{array}{c}\text { COO } \\
\text { Asym. (Sym) }\end{array}$ & $\begin{array}{l}\mathrm{H}_{2} \mathrm{O} \text { Lattice } \\
\text { (coordinate) }\end{array}$ & $\begin{array}{c}\text { M-O COO } \\
\left(\mathrm{H}_{2} \mathrm{O}\right)\end{array}$ & $\begin{array}{c}\text { M-N } \\
(\mathrm{M}-\mathrm{Cl})\end{array}$ \\
\hline $\mathrm{L}_{\text {II }}$ & 3248 & $\begin{array}{c}1744 \\
(1656)\end{array}$ & 1643 & $\begin{array}{c}1621 \\
(1377)\end{array}$ & - & - & - \\
\hline $\mathrm{C}_{7} \mathrm{Co}(\mathrm{II})$ & 3250 & $\begin{array}{c}1731 \\
(1658)\end{array}$ & 1633 & $\begin{array}{c}1610 \\
(1388)\end{array}$ & $\begin{array}{c}3526 \\
(3325,863,760)\end{array}$ & $\begin{array}{c}552 \\
(513)\end{array}$ & $\begin{array}{c}435 \\
(378)\end{array}$ \\
\hline $\mathrm{C}_{8} \mathrm{Ni}(\mathrm{II})$ & 3246 & $\begin{array}{c}1733 \\
(1654)\end{array}$ & 1633 & $\begin{array}{c}1614 \\
(1387)\end{array}$ & $\begin{array}{c}3557 \\
(3406,864,760)\end{array}$ & $\begin{array}{c}552 \\
(513)\end{array}$ & $\begin{array}{c}482 \\
(363)\end{array}$ \\
\hline $\mathrm{C}_{9} \mathrm{Cu}(\mathrm{II})$ & 3250 & $\begin{array}{c}1732 \\
(1658)\end{array}$ & 1633 & $\begin{array}{c}1627 \\
(1388)\end{array}$ & $\begin{array}{c}3526 \\
(3337,865,760)\end{array}$ & $\begin{array}{c}579 \\
(536)\end{array}$ & $\begin{array}{c}435 \\
(363)\end{array}$ \\
\hline $\mathrm{C}_{10} \mathrm{Cd}(\mathrm{II})$ & 3246 & $\begin{array}{c}1730 \\
(1658)\end{array}$ & 1650 & $\begin{array}{c}1641 \\
(1389)\end{array}$ & $\begin{array}{c}3553 \\
(3314,863,762)\end{array}$ & $\begin{array}{l}580 \\
(556)\end{array}$ & $\begin{array}{c}439 \\
(363)\end{array}$ \\
\hline $\mathrm{C}_{11} \mathrm{Pd}(\mathrm{II})$ & 3246 & $\begin{array}{l}1730 \\
(1658)\end{array}$ & 1650 & $\begin{array}{c}1639 \\
(1387)\end{array}$ & 3490 & $\begin{array}{c}580 \\
(552)\end{array}$ & $\begin{array}{c}439 \\
(363)\end{array}$ \\
\hline $\mathrm{C}_{12} \mathrm{Pt}(\mathrm{IV})$ & 3250 & $\begin{array}{c}1731 \\
(1658)\end{array}$ & 1652 & $\begin{array}{c}1640 \\
(1393)\end{array}$ & 3470 & $\begin{array}{c}540 \\
(513)\end{array}$ & $\begin{array}{c}416 \\
(366)\end{array}$ \\
\hline
\end{tabular}


ligands [26]-[28]. The two tables describe also the positions of the bands assigned to vibrational modes of amide $\mathrm{NH}$ groups [15] [28]-[30], $v \mathrm{C}=\mathrm{O}$ of lactam ring of the antibiotic moiety [3] [31] [32], overlapped amide and ester carbonyls [18], the asymmetric and symmetric stretching vibrations respectively of carboxylate anion [3] for both ligands. The -NH- vibrations of the indole ring system [25] and $v \mathrm{C}=\mathrm{O}$ at $\mathrm{C}-2$ [26] [33] of isatin moiety of $\mathrm{L}_{\mathrm{I}}$ (Table 2) are in agreement with those reported in the litrature. The band assigned to $v$ (C-S) stretching vibration was located at (580) $\mathrm{cm}^{-1}$ [1] [5]. The C-N-C and the N-H stretching vibrations of the lactam amide residue in the two ligands were observed at $(1180,1177) \mathrm{cm}^{-1}$ [34] and $3255 \mathrm{~cm}^{-1}$ respectively [3] [17] [29]. The spectrum of the Schiff base ligand $\mathrm{L}_{\mathrm{II}}$ (Table 3) exhibited an additional band observed at (1335) $\mathrm{cm}^{-1}$ assigned to $v$ (C-N) stretching vibration of benzylic moiety [5] [15].

All complexes exhibited shifts in the position of the bands related to the $\beta$-lactam carbonyl ( $v \mathrm{C}=\mathrm{O})$, azomethine groups, $v(-\mathrm{C}=\mathrm{N})$ and carboxylate anion which refers to the coordination of these groups with the metal ions [33] [34]. This was confirmed by the appearance of new low intensity bands at lower wavenumbers corresponding to stretching vibrations of $\mathrm{M}-\mathrm{N}$ and $\mathrm{M}-\mathrm{O}$ bonds respectively [33] [35]. The values of frequency difference $(\Delta v)$ between the two bands of $\left(\mathrm{COO}^{-}\right)$asymmetric and $\left(\mathrm{COO}^{-}\right)$symmetric stretching vibration $\left(>200 \mathrm{~cm}^{-1}\right)$ refers to monodentate coordination behavior of carboxylate group with the metal atoms [29] [34] [35]. These observations suggest that the two Schiff base ligands behaved as tridentate ligands in the coordination with the metal ions [16] [36]. The bands observed at frequency ranges $363-370 \mathrm{~cm}^{-1}$ were assigned to stretching vibrations of (M-Cl) bonds [32] [35]. Bands assigned to vibrational modes of lattice and coordinated waterbonds [35] were also detected and are described in Table 2 and Table 3.

\subsection{Electronic Spectra, Magnetic Moments, and Conductivity Measurements}

The electronic spectrum of Schiff base $\mathrm{L}_{\mathrm{I}}$ in DMSO (Figure 5(a)) exhibited a high intensity band appeared as a doublet with two maximum absorptions at $v_{\max } 37,736$ and $33,223 \mathrm{~cm}^{-1}\left(\varepsilon_{\max } 33,525\right.$ and $40,525 \mathrm{~L} \cdot \mathrm{mol}^{-1} \cdot \mathrm{cm}^{-1}$, respectively) attributed to $\pi \rightarrow \pi^{*}$ transition [5] [15] [37] and a broad low intensity band at $v_{\max } 24,155 \mathrm{~cm}^{-1}$ $\left(\varepsilon_{\max } 275 \mathrm{~L} \cdot \mathrm{mol}^{-1} \cdot \mathrm{cm}^{-1}\right.$ ) which was attributed to $n \rightarrow \pi^{*}$ transition [5] [15] [37]. The spectrum of $\mathrm{L}_{\mathrm{II}}$ in DMSO (Figure 5(b)) exhibited a high intensity band appeared with two absorption maxima at $v_{\max } 33,333$ and 38,168 $\mathrm{cm}^{-1}\left(\varepsilon_{\max } 43,225\right.$ and $42,550 \mathrm{~L} \cdot \mathrm{mol}^{-1} \cdot \mathrm{cm}^{-1}$ respectively) with a shoulder at $v_{\max } 28,986 \mathrm{~cm}^{-1}$ attributed to the $\pi$ $\rightarrow \pi^{*}$ transition and a low intensity band at $v_{\max } 24,570 \mathrm{~cm}^{-1}$ attributed to the $n \rightarrow \pi^{*}$ transition [5] [37]. The spectral data together with molar conductivity and magnetic moments of all metal complexes of $L_{I}$ and $L_{I I}$ in DMSO are described in Table 4 and Table 5 respectively.

The spectra of the metal complexes exhibited bathochromic or hypsochromic shifts of ligand bands. The bands assigned to intraligand $\pi \rightarrow \pi^{*}$ for the $\mathrm{Co}(\mathrm{II}), \mathrm{Ni}(\mathrm{II}), \mathrm{Cu}(\mathrm{II}), \mathrm{Cd}(\mathrm{II}), \mathrm{Pd}(\mathrm{II})$ and $\mathrm{Pt}(\mathrm{IV})$ complexes $\left(\mathrm{C}_{1}-\mathrm{C}_{6}\right)$ were observed at $v_{\max }(38,320,34,483),(38,168,34,722),(38,462,34,483),(38,314,34,247),(38,314,34,483)$ and $21,231 \mathrm{~cm}^{-1}$ respectively, while those of $\mathrm{L}_{\mathrm{II}}$ complexes for the same metal ions $\left(\mathrm{C}_{7}-\mathrm{C}_{12}\right)$ were observed at (38,023, 33,784), (38,314, 33,784), (38,320, 34,247), (38,314, 33,557), $(36,765,30,395)$ and $21,053 \mathrm{~cm}^{-1}$ respectively. The spectra of transition metal complexes showed additional low intensity bands in the visible and near IR regions related to ligand field d-d transitions [38]-[40]. The spectra of the two Co(II) complexes $\left(\mathrm{C}_{1}\right.$ and $\mathrm{C}_{7}$ ) exhibited two additional bands in the visible region attributed respectively to ${ }^{4} \mathrm{~T}_{1} \mathrm{~g} \rightarrow{ }^{4} \mathrm{~A}_{2} \mathrm{~g}_{(\mathrm{F})}\left(v_{2}\right)$ and ${ }^{4} \mathrm{~T}_{1} \mathrm{~g}_{(\mathrm{F})} \rightarrow$
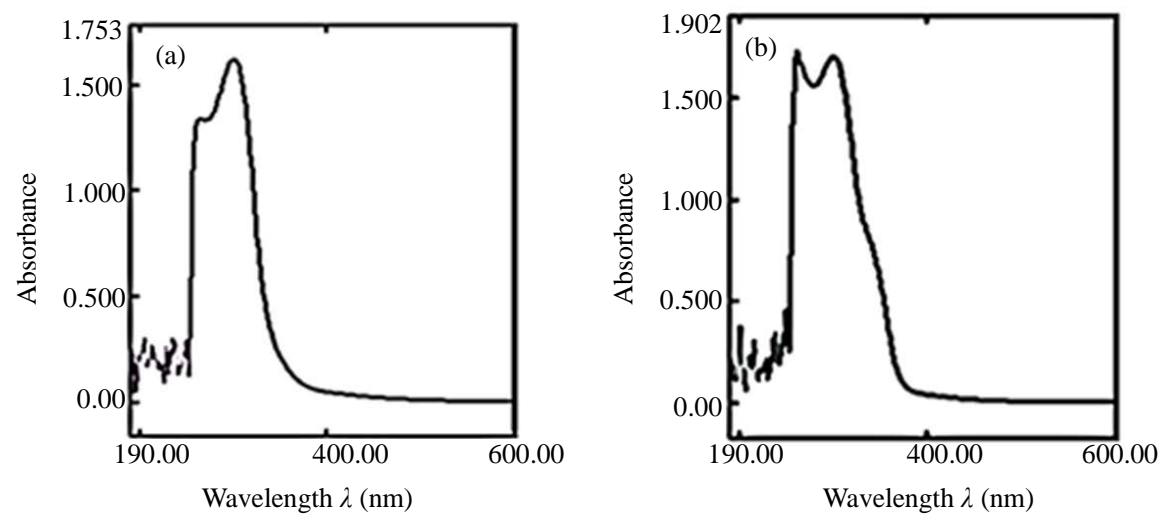

Figure 5. Absorption spectra of (a) $\mathrm{L}_{\mathrm{I}}$ and (b) $\mathrm{L}_{\mathrm{II}}$ in DMSO. 
${ }^{4} \mathrm{~T}_{1} \mathrm{~g}_{(\mathrm{P})}\left(v_{3}\right)$ transitions of octahedral Co(II) complexes [20] [41]. By applying the observed band energies and band ratio $v_{3} / v_{2}$ (1.4 and 1.17 respectively) for the two complexes on Tanabe-Saugano diagram of $\mathrm{d}^{7}$ configuration, the values of $D q / \bar{B}, \bar{B}$ and 10 Dq were obtained (Table 4 and Table 5) and the energy of $v_{1}$ assigned to the transition ${ }^{4} \mathrm{~T}_{1} \mathrm{~g} \rightarrow{ }^{4} \mathrm{~T}_{2} \mathrm{~g}$ for each complex was calculated. The spectra of the two $\mathrm{Ni}(\mathrm{II})$ complexes $\left(\mathrm{C}_{2}\right.$ and $\mathrm{C}_{8}$ ) showed two additional bands appeared in the near IR attributed to the spin allowed transitions ${ }^{3} \mathrm{~A}_{2} \mathrm{~g} \rightarrow{ }^{3} \mathrm{~T}_{2} \mathrm{~g}\left(v_{1}\right)$ and ${ }^{3} \mathrm{~A}_{2} \mathrm{~g} \rightarrow{ }^{3} \mathrm{~T}_{1} \mathrm{~g}(\mathrm{~F})\left(v_{2}\right)$ of octahedral Ni(II) complexes [20] [37]. By applying the two observed band energies and band ratio $v_{2} / v_{1}$ (1.45 and 1.39 respectively) for the two complexes on Tanabe-Saugano diagram of $\mathrm{d}^{8}$ configuration, the values $D q / \bar{B}, \bar{B}$ and 10 Dq were obtained and the energies of $v_{3}$ assigned to the transition ${ }^{3} \mathrm{~A}_{2} \mathrm{~g} \rightarrow$ ${ }^{3} \mathrm{~T}_{1} \mathrm{~g}_{(\mathrm{P})}$ were also calculated. The values of $\beta$ for the cobalt and nickel complexes indicated some covalent character [41]. The values of magnetic moments for the two complexes support the paramagnetic high spin octahedral structures [20] [27] [41]. The spectra of the two $\mathrm{Cu}(\mathrm{II})$ complexes $\left(\mathrm{C}_{3}, \mathrm{C}_{9}\right)$ showed one broad band in the visible region assigned to the ${ }^{2} \mathrm{Eg} \rightarrow{ }^{2} \mathrm{~T}_{2}$ g transition of tetragonally distorted octahedral $\mathrm{Cu}(\mathrm{II})$ complexes [38]-[40]. The magnetic moment of the two $\mathrm{Cu}$ (II) complexes is within the expected values for one unpaired electron [38]-[40]. No d-d transition bands were observed the spectra of the Cd (II) complexes $\left(\mathrm{C}_{4}\right.$ and $\left.\mathrm{C}_{10}\right)$ which were quite common with the $\mathrm{d}^{10}$ complexes [38]-[40].

The spectra of the two diamagnetic Pd(II) complexes $\left(\mathrm{C}_{5}\right.$ and $\left.\mathrm{C}_{11}\right)$ exhibited two additional bands attributed to the transitions ${ }^{1} \mathrm{~A}_{1} \mathrm{~g} \rightarrow{ }^{1} \mathrm{~A}_{2}$ gand ${ }^{1} \mathrm{~A}_{1} \mathrm{~g} \rightarrow{ }^{1} \mathrm{~B}_{1}$ g respectively of square planar geometry [20] [42]. The Pt(IV) complexes $\left(C_{6}, C_{12}\right)$ were diamagnetic and their spectra exhibited the appearance of one additional band attributed to

Table 4. Electronic spectra, spectral parameters, and molar conductivity of $\mathrm{L}_{\mathrm{I}}$ metal complexes.

\begin{tabular}{|c|c|c|c|c|c|c|c|}
\hline Symbol & $\begin{array}{l}\text { Band Positions } \\
\left(\mathrm{cm}^{-1}\right)\end{array}$ & Assignment & $\mathbf{D q} / \bar{B}$ & $\bar{B} \quad\left(\mathrm{~cm}^{-1}\right)(\beta)$ & $\begin{array}{l}10 \text { Dq } \\
\left(\mathrm{cm}^{-1}\right)\end{array}$ & $\begin{array}{l}\text { Molar conductivity } \\
\mathrm{S} \cdot \mathrm{mol}^{-1} \cdot \mathbf{c m}^{2} \text { (DMSO) }\end{array}$ & $\begin{array}{c}\boldsymbol{\mu}_{\text {eff }} \text { B.M. } \\
\text { (geom) }\end{array}$ \\
\hline $\mathrm{C}_{1} \mathrm{Co}(\mathrm{II})$ & $\begin{array}{l}v_{1} 6471 \text { (cal.) } \\
v_{2} 14,620 \\
v_{3} 20,620\end{array}$ & $\begin{array}{l}{ }^{4} \mathrm{~T}_{1} \mathrm{~g} \rightarrow{ }^{4} \mathrm{~T}_{2 \mathrm{~g}}(\mathrm{~F}) \\
{ }^{4} \mathrm{~T}_{1 \mathrm{~g}} \rightarrow{ }^{4} \mathrm{~A}_{2} \mathrm{~g}(\mathrm{~F}) \\
{ }^{4} \mathrm{~T}_{1 \mathrm{~g}} \rightarrow{ }^{4} \mathrm{~T}_{1 \mathrm{~g}}(\mathrm{P})\end{array}$ & 0.8 & $895(0.922)$ & 7160 & 0.0085 & $4.36(\mathrm{Oh})$ \\
\hline $\mathrm{C}_{2} \mathrm{Ni}(\mathrm{II})$ & $\begin{array}{l}v_{1} 12,285 \\
v_{2} 17,857 \\
v_{3} 28,800 \text { (cal.) }\end{array}$ & $\begin{array}{l}{ }^{3} \mathrm{~A}_{2} \mathrm{~g} \rightarrow{ }^{3} \mathrm{~T}_{2} \mathrm{~g} \\
{ }^{3} \mathrm{~A}_{2} \mathrm{~g} \rightarrow{ }^{3} \mathrm{~T}_{1} \mathrm{~g}(\mathrm{~F}) \\
{ }^{3} \mathrm{~A}_{2} \mathrm{~g} \rightarrow{ }^{3} \mathrm{~T}_{1} \mathrm{~g}(\mathrm{P})\end{array}$ & 2.2 & $576(0.56)$ & 12670 & 0.01595 & $3.86(\mathrm{Oh})$ \\
\hline $\mathrm{C}_{3} \mathrm{Cu}(\mathrm{II})$ & $\begin{array}{l}v_{1} 16,667 \\
v_{2} 34,483\end{array}$ & ${ }^{2} \mathrm{Eg} \rightarrow{ }^{2} \mathrm{~T}_{2} \mathrm{~g}$ & - & - & - & 0.0453 & $1.66(\mathrm{Oh})$ \\
\hline $\mathrm{C}_{4} \mathrm{Cd}(\mathrm{II})$ & $\begin{array}{l}v_{1} 38,314 \\
v_{2} 34,247\end{array}$ & $\begin{array}{l}\text { IL } \pi \rightarrow \pi^{*} \\
\text { Il } \pi \rightarrow \pi^{*}\end{array}$ & - & - & - & 0.0065 & Diam. (Oh) \\
\hline $\mathrm{C}_{5} \mathrm{Pd}(\mathrm{II})$ & $\begin{array}{l}v_{1} 17,668 \\
v_{2} 22,272\end{array}$ & $\begin{array}{l}{ }^{1} \mathrm{~A}_{1} \mathrm{~g} \rightarrow{ }^{1} \mathrm{~A}_{2} \mathrm{~g} \\
{ }^{1} \mathrm{~A}_{1} \mathrm{~g} \rightarrow{ }^{1} \mathrm{~B}_{1} \mathrm{~g}\end{array}$ & - & - & - & 0.012 & Diam. (Sq.p) \\
\hline $\mathrm{C}_{6} \mathrm{Pt}(\mathrm{IV})$ & $\begin{array}{l}v_{1} 38,023 \\
v_{2} 21,231\end{array}$ & $\begin{array}{l}\mathrm{IL} \pi \rightarrow \pi^{*} \\
{ }^{1} \mathrm{~A}_{1} \mathrm{~g} \rightarrow{ }^{3} \mathrm{~T}_{2} \mathrm{~g}\end{array}$ & - & - & - & 0.0589 & Diam. (Oh) \\
\hline
\end{tabular}

Table 5. Electronic spectra, spectral parameters, and molar conductivity of $\mathrm{L}_{\mathrm{II}}$ metal complexes.

\begin{tabular}{|c|c|c|c|c|c|c|c|}
\hline Symbol & $\begin{array}{c}\text { Band Positions } \\
\left(\mathrm{cm}^{-1}\right)\end{array}$ & assignment & $\mathbf{D q} / \bar{B}$ & $\bar{B}\left(\mathrm{~cm}^{-1}\right)(\beta)$ & $\begin{array}{l}10 \mathrm{Dq} \\
\left(\mathrm{cm}^{-1}\right)\end{array}$ & $\begin{array}{l}\text { Molar Conductivity } \\
\text { S } \cdot \mathbf{m o l}^{-1} \cdot \mathbf{m}^{2} \text { (DMSO) }\end{array}$ & $\begin{array}{c}\mu_{\text {eff }} \text { B.M } \\
\text { (geom) }\end{array}$ \\
\hline $\mathrm{C}_{8} \mathrm{Co}(\mathrm{II})$ & $\begin{array}{l}v_{1} 7092 \text { (cal.) } \\
v_{2} 15,723 \\
v_{3} 18,519\end{array}$ & $\begin{array}{l}{ }^{4} \mathrm{~T} 1 \mathrm{~g} \rightarrow{ }^{4} \mathrm{~T}_{2 \mathrm{~g}}(\mathrm{~F}) \\
{ }^{4} \mathrm{~T}_{1 \mathrm{~g}} \rightarrow{ }^{4} \mathrm{~A}_{2} \mathrm{~g}(\mathrm{~F}) \\
{ }^{4} \mathrm{~T}_{1 \mathrm{~g}} \rightarrow{ }^{4} \mathrm{~T}_{1 \mathrm{~g}}(\mathrm{P})\end{array}$ & 1.0 & 813 (0.837) & 8130 & 0.0107 & $4.4(\mathrm{Oh})$ \\
\hline $\mathrm{C}_{7} \mathrm{Ni}(\mathrm{II})$ & $\begin{array}{l}v_{1} 11,442 \\
v_{2} 15,924 \\
v_{3} 29,812 \text { (cal.) }\end{array}$ & $\begin{array}{l}{ }^{3} \mathrm{~A}_{2} \mathrm{~g} \rightarrow{ }^{3} \mathrm{~T}_{2} \mathrm{~g} \\
{ }^{3} \mathrm{~A}_{2} \mathrm{~g} \rightarrow{ }^{3} \mathrm{~T}_{1} \mathrm{~g}(\mathrm{~F}) \\
{ }^{3} \mathrm{~A}_{2} \mathrm{~g} \rightarrow{ }^{3} \mathrm{~T}_{1} \mathrm{~g}(\mathrm{P})\end{array}$ & 2.6 & $514(0.5)$ & 13,364 & 0.0077 & 2.9 (Oh) \\
\hline $\mathrm{C}_{9} \mathrm{Cu}(\mathrm{II})$ & $v_{1} 16,234$ & ${ }^{2} \mathrm{Eg} \rightarrow{ }^{2} \mathrm{~T}_{2} \mathrm{~g}$ & - & - & - & 0.0066 & $1.66(\mathrm{Oh})$ \\
\hline $\mathrm{C}_{10} \mathrm{Cd}(\mathrm{II})$ & $\begin{array}{l}v_{1} 38,314 \\
v_{2} 33,557\end{array}$ & $\begin{array}{l}\mathrm{IL} \pi \rightarrow \pi^{*} \\
\mathrm{IL} \pi \rightarrow \pi^{*}\end{array}$ & - & - & & 0.0054 & Diam. (Oh) \\
\hline $\mathrm{C}_{11} \mathrm{Pd}(\mathrm{II})$ & $\begin{array}{l}v_{1} 17,762 \\
v_{2} 22,075\end{array}$ & $\begin{array}{l}{ }^{1} \mathrm{~A}_{1} \mathrm{~g} \rightarrow{ }^{1} \mathrm{~A}_{2} \mathrm{~g} \\
{ }^{1} \mathrm{~A}_{1} \mathrm{~g} \rightarrow{ }^{1} \mathrm{~B}_{1} \mathrm{~g}\end{array}$ & - & - & & 0.011 & Diam. (Sq.p) \\
\hline $\mathrm{C}_{12} \mathrm{Pt}(\mathrm{IV})$ & $\begin{array}{l}v_{1} 38,023 \\
v_{2} 21,053\end{array}$ & $\begin{array}{l}\text { IL } \pi \rightarrow \pi^{*} \\
{ }^{1} \mathrm{~A}_{1} \mathrm{~g} \rightarrow{ }^{3} \mathrm{~T}_{1} \mathrm{~g}\end{array}$ & & & & 0.0699 & Diam. (Oh) \\
\hline
\end{tabular}


${ }^{1} \mathrm{~A}_{1} \mathrm{~g} \rightarrow{ }^{3} \mathrm{~T}_{2} \mathrm{~g}$ transitions of octahedral Pt(IV) complexes [42]. The molar conductivity measurements of all metal complexes in DMSO $\left(10^{-3} \mathrm{M}\right)$ suggested that the complexes were nonelectrolyte [43]. According to these data, together with elemental analyses and I.R. spectra, the structures of metal complexes were suggested as illustrated in Scheme 2.

\subsection{Thermo Gravimetric Analysis}

The TGA analyses of the two ligands and some selected metal complexes described in (Table 6). The TG curves of the two ligands refer to three decomposition steps. In the first step the weight loss corresponds to the elimination of solvent molecules (alcohol and water molecules) embedded in the crystal lattice at peak temperature 65 $-100^{\circ} \mathrm{C}$ as is demonstrated by DTG curves data, which agrees with the elemental and IR analysis of the studied samples. The second and third steps involved the thermal decomposition of the ligands. The thermal decomposition

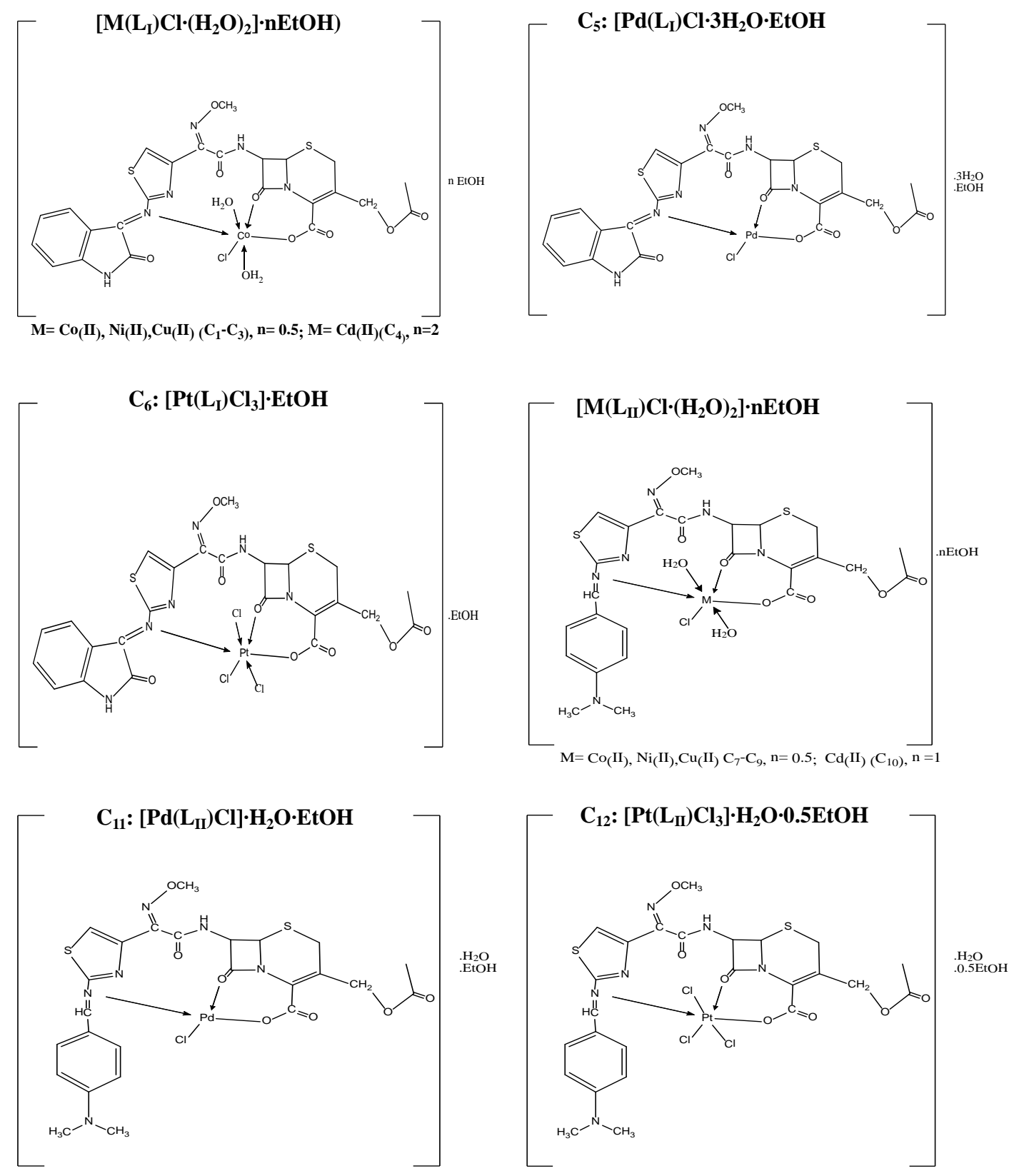

Scheme 2. Suggested stereochemical structures of the cefotaxime Schiff base metal complexes. 
Table 6. Thermal decomposition of $\mathrm{L}_{\mathrm{I}}, \mathrm{L}_{\mathrm{II}}$ and some selected metal complexes.

\begin{tabular}{|c|c|c|c|c|}
\hline Stable phase Molecular weight & $\begin{array}{l}\text { Decomposition } \\
\text { steps }\end{array}$ & $\begin{array}{l}\text { TG temp. range } \\
\text { of decomp. }\left({ }^{\circ} \mathrm{C}\right)\end{array}$ & $\begin{array}{l}\text { Peak temp. } \\
\text { of DTG }\left({ }^{\circ} \mathrm{C}\right)\end{array}$ & $\begin{array}{l}\text { \% wt. loss (TG) } \\
\text { Found (Calc.) }\end{array}$ \\
\hline \multirow[t]{4}{*}[\mathrm{C}_{24}\mathrm{H}_{19}\mathrm{N}_{6}\mathrm{O}_{8}\mathrm{S}_{2}\mathrm{Na}]{$\cdot 0.5 \mathrm{MeOH}\left(\mathrm{L}_{\mathrm{I}}\right) 622.63 \mathrm{~g} / \mathrm{mole}$} & $-\downarrow 0.5 \mathrm{MeOH}$ & $25-95$ & 80 & $2.5(2.57)$ \\
\hline & $\begin{array}{l}-\downarrow \mathrm{C}_{3} \mathrm{H}_{5} \mathrm{O}_{2} \\
-\downarrow \mathrm{C}_{8} \mathrm{H}_{6} \mathrm{~N}_{2} \mathrm{O}\end{array}$ & $96-360$ & 275 & 35 (35.17) \\
\hline & $-\downarrow \mathrm{C}_{6} \mathrm{H}_{3} \mathrm{~N}_{2} \mathrm{O}_{2} \mathrm{~S}$ & $361-800$ & & $27.0(26.8)$ \\
\hline & $\mathrm{C}_{7} \mathrm{H}_{5} \mathrm{~N}_{2} \mathrm{O}_{3} \mathrm{SNa}$ & & & 35.5 (35.33) \\
\hline \multirow[t]{4}{*}[\mathrm{Co}(\mathrm{L}_{\mathrm{I}})\mathrm{Cl}\cdot2\mathrm{H}_{2}\mathrm{O}]{$0.5 \mathrm{EtOH}\left(\mathrm{C}_{1}\right) 737.063 \mathrm{~g} / \mathrm{mole}$} & $-\downarrow 0.5 \mathrm{EtOH}$ & $25-85$ & 85 & $3.0(3.1)$ \\
\hline & $\begin{array}{l}-\downarrow 2 \mathrm{H}_{2} \mathrm{O} \\
-\downarrow \mathrm{C}_{3} \mathrm{H}_{5} \mathrm{O}_{2} \\
-\downarrow \mathrm{C}_{8} \mathrm{H}_{6} \mathrm{~N}_{2} \mathrm{O}\end{array}$ & $86-345$ & 265 & 34.5 (34.58) \\
\hline & $-\downarrow \mathrm{C}_{6} \mathrm{H}_{4} \mathrm{~N}_{3} \mathrm{O}_{2} \mathrm{~S}$ & $346-800$ & - & $25.0(24.7)$ \\
\hline & $\mathrm{C}_{7} \mathrm{H}_{4} \mathrm{NO}_{3} \mathrm{SCoCl}$ & & - & $37.5(37.5)$ \\
\hline \multirow[t]{4}{*}[\mathrm{Cd}(\mathrm{L}_{\mathrm{I}})\mathrm{Cl}\cdot2\mathrm{H}_{2}\mathrm{O}]{$\cdot 2 \mathrm{EtOH}\left(\mathrm{C}_{4}\right) 859.54 \mathrm{~g} / \mathrm{mol}$} & $-\downarrow 2 \mathrm{EtOH}$ & $25-200$ & 100 & $10.0(10.48)$ \\
\hline & $\begin{array}{l}-\downarrow 2 \mathrm{H}_{2} \mathrm{O} \\
-\downarrow \mathrm{C}_{3} \mathrm{H}_{5} \mathrm{O}_{2} \\
-\downarrow \mathrm{C}_{8} \mathrm{H}_{6} \mathrm{~N}_{2} \mathrm{O}\end{array}$ & $201-370$ & 270 & $30.0(29.67)$ \\
\hline & $-\downarrow \mathrm{C}_{6} \mathrm{H}_{4} \mathrm{~N}_{3} \mathrm{O}_{2} \mathrm{~S}$ & $371-808$ & - & 21.5 (21.17) \\
\hline & $\mathrm{C}_{7} \mathrm{H}_{4} \mathrm{NO}_{3} \mathrm{SCdCl}$ & - & - & 38.5 (38.38) \\
\hline \multirow[t]{4}{*}[\mathrm{Pd}(\mathrm{L}_{\mathrm{I}})\mathrm{Cl}]{$\cdot 3 \mathrm{H}_{2} \mathrm{O} \cdot \mathrm{EtOH}\left(\mathrm{C}_{5}\right) 825.55 \mathrm{~g} / \mathrm{mol}$} & $\begin{array}{l}-\downarrow \mathrm{EtOH} \\
-\downarrow 3 \mathrm{H}_{2} \mathrm{O}\end{array}$ & $28-236$ & 67.99 & $11.66(12.11)$ \\
\hline & $\begin{array}{l}-\downarrow \mathrm{C}_{3} \mathrm{H}_{5} \mathrm{O}_{2} \\
-\downarrow \mathrm{C}_{8} \mathrm{H}_{6} \mathrm{~N}_{2} \mathrm{O}\end{array}$ & $237-405$ & 263.89 & $26.6(26.53)$ \\
\hline & $-\downarrow \mathrm{C}_{10} \mathrm{H}_{6} \mathrm{~N}_{3} \mathrm{O}_{2} \mathrm{~S}_{2}$ & $406-839$ & - & $32.585(32.1)$ \\
\hline & $\mathrm{C}_{3} \mathrm{H}_{2} \mathrm{O}_{3} \mathrm{NPdCl}$ & - & - & 29.155 (29.18) \\
\hline \multirow[t]{5}{*}[\mathrm{Pt}(\mathrm{L}_{\mathrm{I}})\mathrm{Cl}_{3}]{$\cdot \mathrm{EtOH} 931.21 \mathrm{~g} / \mathrm{mole}$} & $-\downarrow \mathrm{EtOH}$ & $28-89$ & 72.05 & $4.88(4.9)$ \\
\hline & $-\downarrow \mathrm{C}_{8} \mathrm{H}_{6} \mathrm{~N}_{2} \mathrm{O}$ & $90-250$ & 231.00 & $15.57(15.46)$ \\
\hline & $-\downarrow \mathrm{Cl}_{2}+\mathrm{CO}+\mathrm{C}_{3} \mathrm{H}_{5} \mathrm{O}_{2}$ & $251-394$ & 272.17 & $18.87(18.9)$ \\
\hline & $-\downarrow \mathrm{C}_{12} \mathrm{H}_{8} \mathrm{~N}_{4} \mathrm{O}_{3} \mathrm{~S}_{2}$ & $395-839$ & 532.91 & $34.16(34.15)$ \\
\hline & $1 / 2 \mathrm{PtO}_{2}+1 / 2 \mathrm{PtCl}_{2}$ & - & - & $26.43(26.48)$ \\
\hline \multirow[t]{4}{*}[\mathrm{C}_{25}\mathrm{H}_{25}\mathrm{N}_{6}\mathrm{O}_{7}\mathrm{S}_{2}\mathrm{Na}]{$\cdot 0.5 \mathrm{MeOH}\left(\mathrm{L}_{\mathrm{II}}\right) 624.866 \mathrm{~g} / \mathrm{mol}$} & $-\downarrow 0.5 \mathrm{MeOH}$ & $33-67$ & 63.14 & $2.6(2.56)$ \\
\hline & $\begin{array}{l}-\downarrow \mathrm{C}_{3} \mathrm{H}_{5} \mathrm{O}_{2} \\
-\downarrow \mathrm{C}_{9} \mathrm{H}_{12} \mathrm{~N}_{2}\end{array}$ & $68-325$ & 262.88 & $35.3(35.37)$ \\
\hline & $-\downarrow \mathrm{C}_{11} \mathrm{H}_{8} \mathrm{~N}_{3} \mathrm{O}_{3} \mathrm{~S}_{2}$ & $326-811$ & 702.55 & $47.3(47.05)$ \\
\hline & $\mathrm{C}_{2} \mathrm{NO}_{2} \mathrm{Na}$ & - & - & $14.8(14.88)$ \\
\hline \multirow[t]{4}{*}[\mathrm{Cd}(\mathrm{L}_{\mathrm{II}})\mathrm{Cl}\cdot2\mathrm{H}_{2}\mathrm{O}]{$\cdot \mathrm{EtOH}\left(\mathrm{C}_{10}\right) 859.54 \mathrm{~g} / \mathrm{mol}$} & $-\downarrow \mathrm{EtOH}$ & $25-110$ & 90 & $6.0(5.64)$ \\
\hline & $\begin{array}{l}-\downarrow 2 \mathrm{H}_{2} \mathrm{O} \\
-\downarrow \mathrm{C}_{3} \mathrm{H}_{5} \mathrm{O}_{2} \\
-\downarrow \mathrm{C}_{9} \mathrm{H}_{12} \mathrm{~N}_{2}\end{array}$ & $111-340$ & 270 & 31.44 (31.37) \\
\hline & $-\downarrow \mathrm{C}_{6} \mathrm{H}_{4} \mathrm{~N}_{3} \mathrm{O}_{2} \mathrm{~S}$ & $341-800$ & - & $22.56(22.3)$ \\
\hline & $\mathrm{C}_{7} \mathrm{H}_{4} \mathrm{NO}_{3} \mathrm{SCdCl}$ & - & - & $40.0(40.44)$ \\
\hline \multirow[t]{4}{*}[\mathrm{Pd}(\mathrm{L}_{\mathrm{II}})\mathrm{Cl}]{$\cdot \mathrm{H}_{2} \mathrm{O} \cdot \mathrm{EtOH}\left(\mathrm{C}_{11}\right) 791.61 \mathrm{~g} / \mathrm{mol}$} & $\begin{array}{l}-\downarrow \mathrm{EtOH} \\
-\downarrow \mathrm{H}_{2} \mathrm{O}\end{array}$ & $33-200$ & 83.80 & $7.6(8.08)$ \\
\hline & $\begin{array}{l}-\downarrow \mathrm{C}_{3} \mathrm{H}_{5} \mathrm{O}_{2} \\
-\downarrow \mathrm{C}_{9} \mathrm{H}_{12} \mathrm{~N}_{2}\end{array}$ & $201-361$ & 269.77 & $27.9(27.92)$ \\
\hline & $-\downarrow \mathrm{C}_{11} \mathrm{H}_{8} \mathrm{~N}_{3} \mathrm{O}_{3} \mathrm{~S}_{2}$ & $362-833$ & 485.59 & $37.48(37.14)$ \\
\hline & $\mathrm{C}_{2} \mathrm{O}_{2} \mathrm{NPdCl}$ & - & - & 26.677 (26.77) \\
\hline \multirow[t]{4}{*}[\mathrm{Pt}(\mathrm{L}_{\mathrm{II}})\mathrm{Cl}_{3}]{$\cdot \mathrm{H}_{2} \mathrm{O} \cdot 0.5 \mathrm{EtOH}\left(\mathrm{C}_{12}\right) 928.27 \mathrm{~g} / \mathrm{mol}$} & $\begin{array}{l}-\downarrow 0.5 \mathrm{EtOH} \\
-\downarrow \mathrm{H}_{2} \mathrm{O}\end{array}$ & $25-120$ & 95 & $4.5(4.4)$ \\
\hline & $\begin{array}{l}-\downarrow \mathrm{C}_{3} \mathrm{H}_{5} \mathrm{O}_{2} \\
-\downarrow \mathrm{C}_{9} \mathrm{H}_{12} \mathrm{~N}_{2}\end{array}$ & $121-290$ & 220 & $23.5(23.8)$ \\
\hline & $-\downarrow \mathrm{C}_{8} \mathrm{H}_{4} \mathrm{~N}_{3} \mathrm{O}_{3} \mathrm{~S}$ & $291-800$ & 360 & $24.0(23.9)$ \\
\hline & $\mathrm{C}_{5} \mathrm{H}_{4} \mathrm{NO}_{2} \mathrm{SPtCl}_{3}$ & - & - & 48.0 (47.79) \\
\hline
\end{tabular}


of $\mathrm{L}_{\mathrm{I}}$ showed similar behavior to other isatin Schiff bases mentioned in the literature [21] [22] [44]. In the second step, the weight losses were mainly attributed to the removal of the isatinazomethinic moiety [22] [44] [45], as well as the methyl ester substituent at the fused six membered thiazin ring. The third step was attributed to the removal of the substituted thiazole ring and its side chain moiety by amide bond breaking, leaving the fused ring $\beta$-lactam sodium salt as the residual part of the ligand. The weight losses demonstrated by TG curves of the $\mathrm{Co}(\mathrm{II})$ and $\mathrm{Cd}(\mathrm{II})$ complexes $\left(\mathrm{C}_{1}, \mathrm{C}_{4}\right)$ were attributed to the loss of coordinated water together with coordinated isatinazomethinic moiety and methyl ester substituent. The third stage is similar to that of the original ligand.

The DTA curve of the $\mathrm{Cd}\left(\mathrm{C}_{4}\right)$ complex (Figure 6(a)) shows a broad endothermic peak in the range $\left(301^{\circ} \mathrm{C}\right.$ $500^{\circ} \mathrm{C}$ ) which corresponds to the partial removal of the coordinated part of the complexes and an exothermic broad peak at temperature range (501 - 808). The final residue of the complex corresponds to the metal ion bonded to the chloride and carboxylate anion at the fused $\beta$-lactam rings fragments. The total weight losses exhibited by the $\mathrm{Pd}(\mathrm{II}) \mathrm{L}_{\mathrm{I}}$ and $\mathrm{Pt}(\mathrm{II}) \mathrm{L}_{\mathrm{I}}$ complexes $\left(\mathrm{C}_{5}\right.$ and $\left.\mathrm{C}_{6}\right)$ were $(71 \%-73 \%)$ up to $839^{\circ} \mathrm{C}$ are summarized in three steps for the former and four steps for the latter. The mass losses displayed by the thermal decomposition of $\mathrm{L}_{\mathrm{II}}$ and its selected $\mathrm{Cd}(\mathrm{II}), \mathrm{Pd}(\mathrm{II})$ and $\mathrm{Pt}(\mathrm{IV})$ complexes $\left(\mathrm{C}_{10}, \mathrm{C}_{11}\right.$ and $\left.\mathrm{C}_{12}\right)$ in the first and second steps correspond to the departure of lattice solvent and to methyl ester $+\mathrm{N}$, N-dimethyl benzyl imino moieties respectively in addition to coordinated water molecules in the case of Cd (II) $\mathrm{L}_{\mathrm{II}}$ complex. The maximum weight loss in the third step was due to the loss of thiazole ring and its side chain up to the remaining part of the $\beta$-lactam moiety. The DTA curve of the Cd(II) complex $\left(\mathrm{C}_{10}\right)$ (Figure 6(b)) showed two endothermic peaks at the temperature ranges $\left(25^{\circ} \mathrm{C}-310^{\circ} \mathrm{C}\right)$ and $\left(311^{\circ} \mathrm{C}-420^{\circ} \mathrm{C}\right)$ corresponding to the mass loss of the first and second steps. The exothermic peak at the temperature range $\left(421^{\circ} \mathrm{C}-800^{\circ} \mathrm{C}\right)$ is attributable to the third step. The maximum weight loss of the $\mathrm{Pd}(\mathrm{II})$ complex observed in the third step refers to almost complete degradation of the ligand. The DTA curve of the $\mathrm{Pt}(\mathrm{IV})$ complex $\left(\mathrm{C}_{12}\right)$ (Figure 6(c)) indicated three steps. The first is an endothermic step in the range $\left(25^{\circ} \mathrm{C}-270^{\circ} \mathrm{C}\right)$ corresponding to the loss of solvents together with the methyl ester and the coordinated N, N-dimethylaminobenzylimino moieties. The second step shows endothermic and exothermic decomposition reactions in the range $\left(271^{\circ} \mathrm{C}-600^{\circ} \mathrm{C}\right)$ which corresponds to further decomposition of the uncoordinated parts of the ligand. In the third step an exothermic peak was observed at temperature range $\left(600^{\circ} \mathrm{C}-800^{\circ} \mathrm{C}\right)$ corresponding to the formation of the final product.

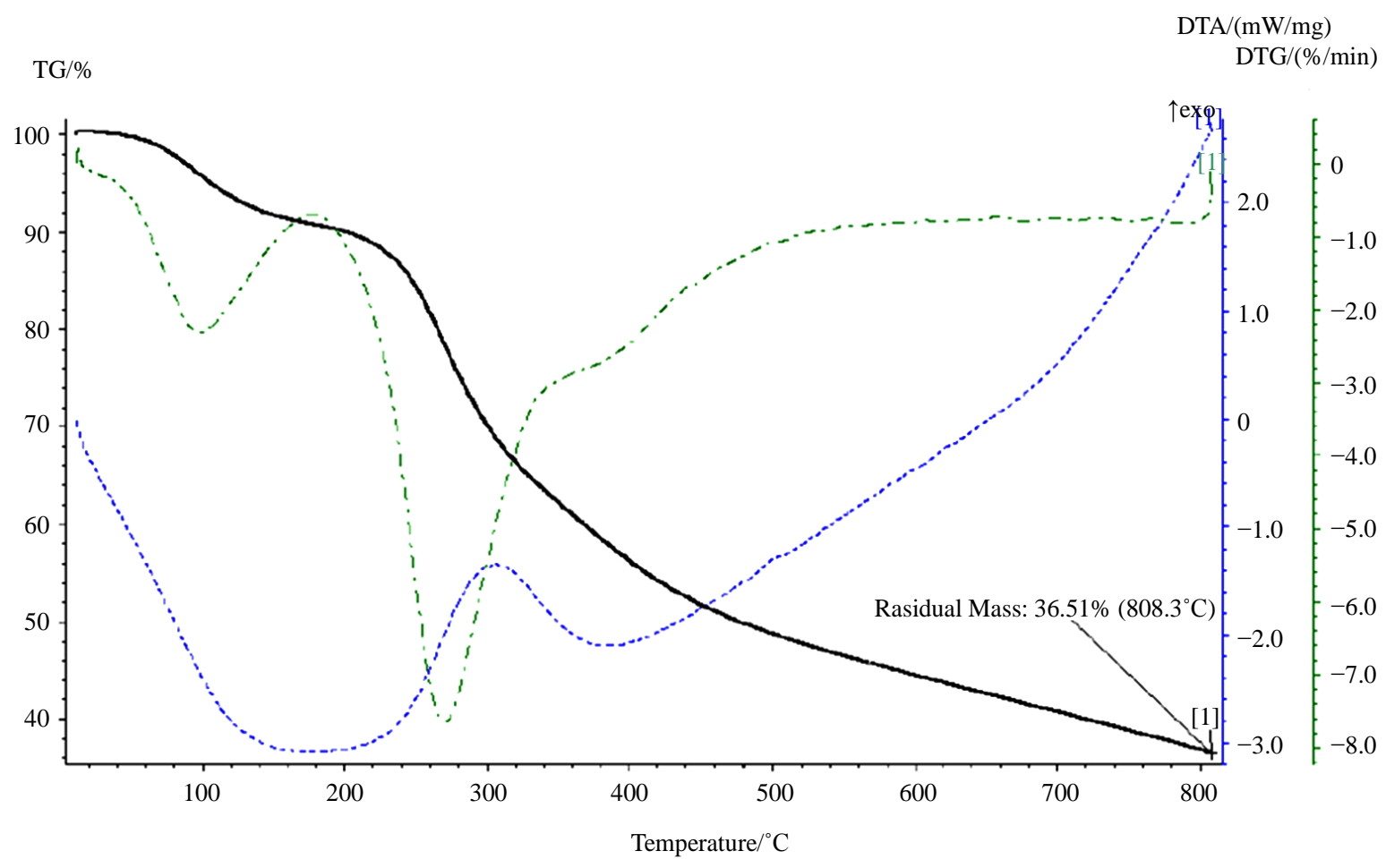

(a) 


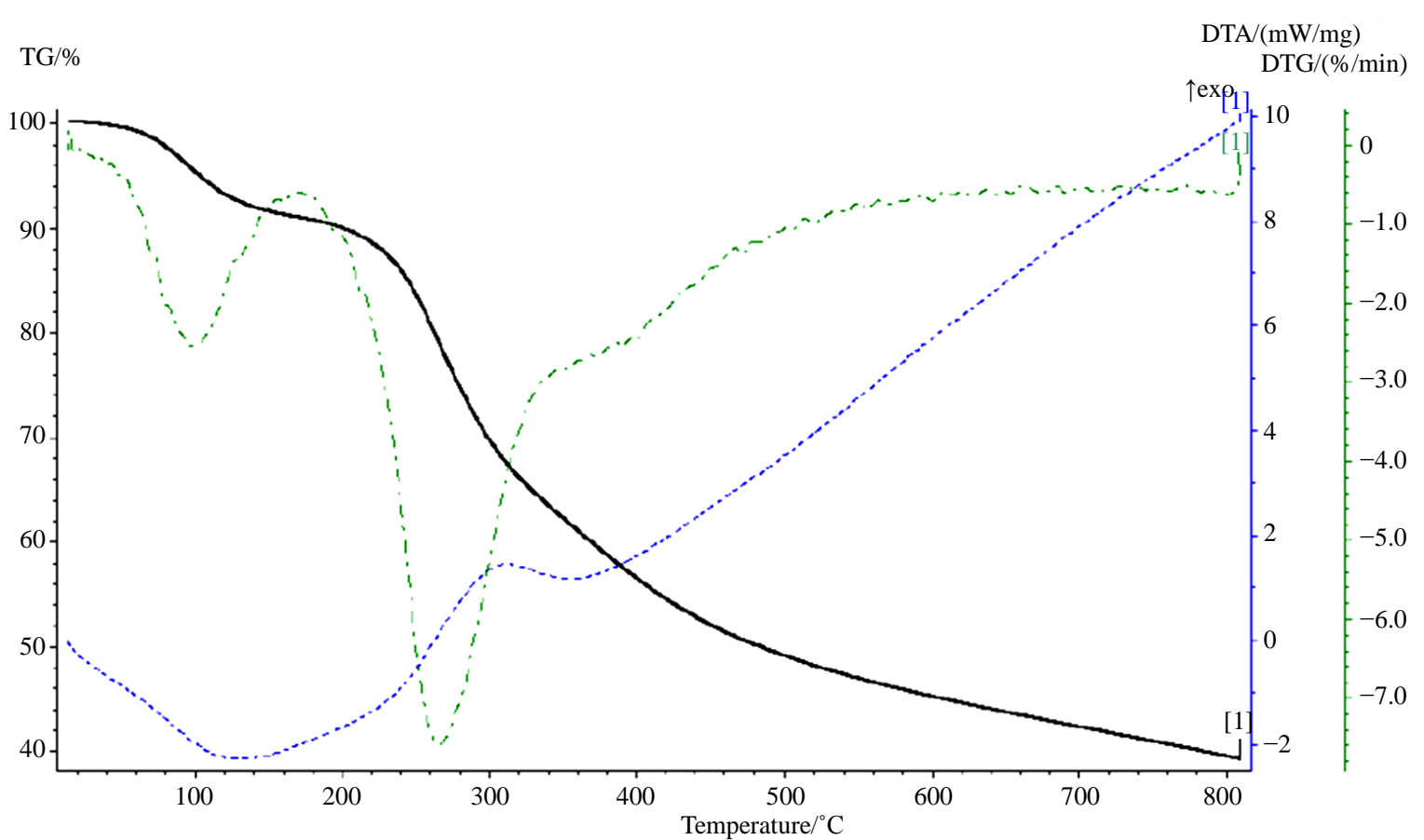

(b)

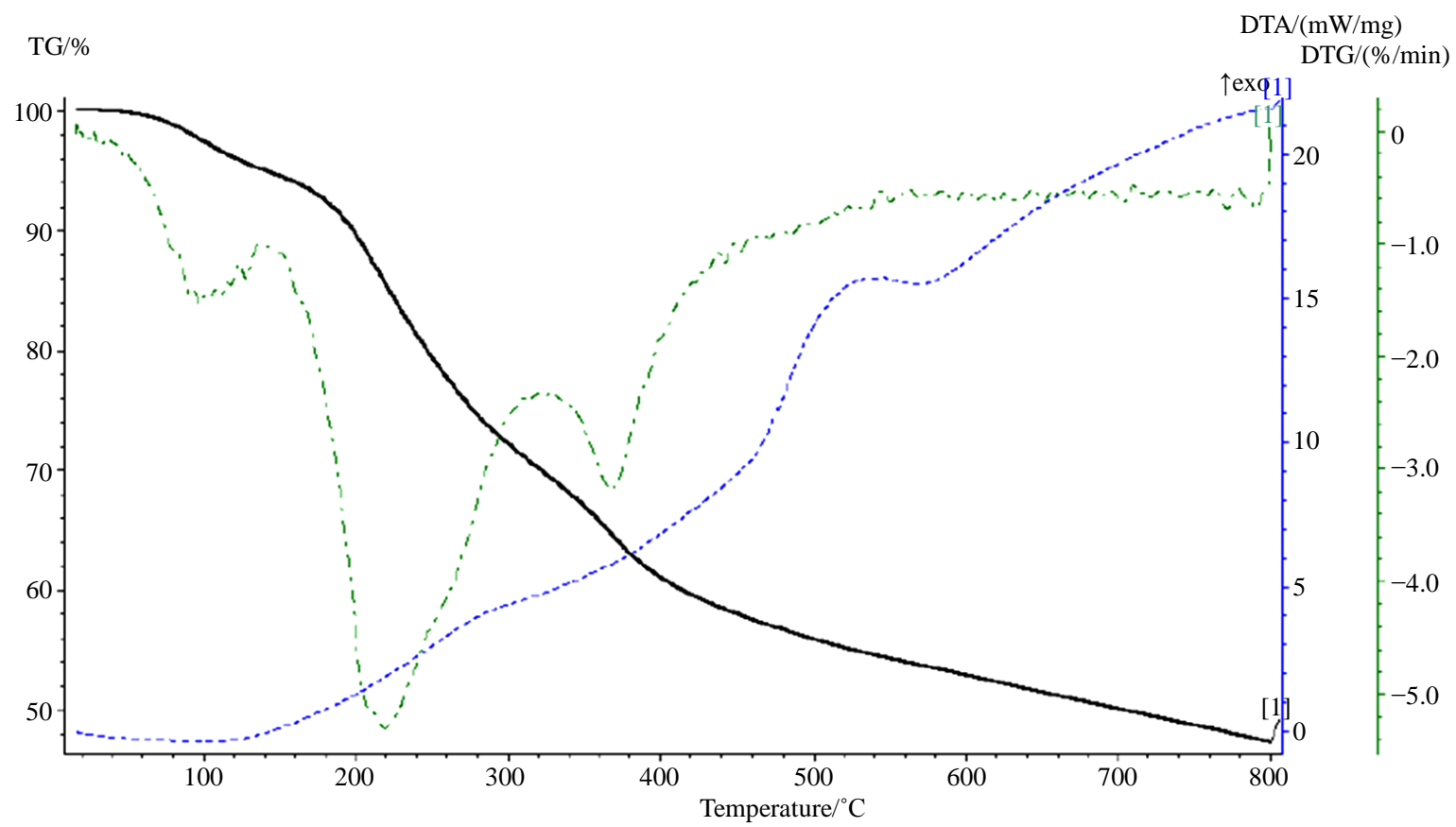

(c)

Figure 6. Thermo grams of a-Cd (II) $\mathrm{L}_{\mathrm{I}}\left(\mathrm{C}_{4}\right)$, b-Cd (II) $\mathrm{L}_{\mathrm{II}}\left(\mathrm{C}_{10}\right)$ and c-Pt (IV) $\mathrm{L}_{\mathrm{II}}\left(\mathrm{C}_{12}\right)$ complexes.

\subsection{Antibacterial Activity}

Evaluation of antimicrobial activity of all compounds in DMSO $(1 \mathrm{mg} / \mathrm{ml})$ in vitro was carried out against E. coli, Staphylococcus aureus, Pseudomonas aeruginosa and Streptococcus pneumonia utilizing the agar diffusion technique. The antibiotic showed a selective antibacterial activity as it exhibited no inhibition zone against Pseudomonas aeroginosa, a weak growth inhibition against Streptococcus pneumonia, a moderate growth inhi- 
bition against Staphylococcus aureus and a high growth inhibition against E. coli. The two Schiff base ligands were completely inactive against all the studied cultures at the selected concentration, which indicates that the amino group of the original antibiotic plays an important role in growth inhibition activity. All metal complexes showed selective activity against one or two bacteria except the complex $\left[\mathrm{Pt}\left(\mathrm{L}_{\text {II }}\right) \mathrm{Cl}_{3}\right] \mathrm{H}_{2} \mathrm{O} \cdot 0.5 \mathrm{EtOH}$ which was active against all cultures and exhibited higher activities against Streptococcus pneumonia and Pseudomonas aeroginosacompared with the free antibiotic (Cefotaxim). The complexes $\left[\mathrm{Co}\left(\mathrm{L}_{\mathrm{I}}\right) \mathrm{Cl} \cdot\left(\mathrm{H}_{2} \mathrm{O}\right)_{2}\right] \cdot 0.5(\mathrm{EtOH})$, $\left[\mathrm{Cu}\left(\mathrm{L}_{\mathrm{I}}\right) \mathrm{Cl} \cdot\left(\mathrm{H}_{2} \mathrm{O}\right)_{2}\right] \cdot 0.5(\mathrm{EtOH}),\left[\mathrm{Ni}\left(\mathrm{L}_{\mathrm{II}}\right) \mathrm{Cl} \cdot\left(\mathrm{H}_{2} \mathrm{O}\right)_{2}\right] \cdot 0.5(\mathrm{EtOH})$ and; $\left[\mathrm{Pd}\left(\mathrm{L}_{\mathrm{II}}\right) \mathrm{Cl}\right] \cdot \mathrm{H}_{2} \mathrm{O} \cdot \mathrm{EtOH}$ were found moderately active against Staphylococcusaureus especially the copper complex which showed comparable bactericidal activity with the original drug. The other metal complexes showed selective activity against one type of bacteria at a range starting from highest activity of $\left[\mathrm{Co}\left(\mathrm{L}_{\mathrm{I}}\right) \mathrm{Cl} \cdot\left(\mathrm{H}_{2} \mathrm{O}\right)_{2}\right] \cdot 0.5 \mathrm{EtOH}$ against E. coli, $\left[\mathrm{Pt}\left(\mathrm{L}_{\mathrm{I}}\right) \mathrm{Cl}_{3}\right] \cdot \mathrm{EtOH}$ against Staphylococcusaureus, $\left[\mathrm{Ni}\left(\mathrm{L}_{\mathrm{II}}\right) \mathrm{Cl} \cdot\left(\mathrm{H}_{2} \mathrm{O}\right)_{2}\right] \cdot 0.5(\mathrm{EtOH})$, against $E$. coli to the lowest activity of $\left[\mathrm{Cd}\left(\mathrm{L}_{\mathrm{II}}\right)\left(\mathrm{H}_{2} \mathrm{O}\right)_{2} \mathrm{Cl}\right]$. EtO H against Pseudomonas aeroginosa. These results imply that the type of metal ions and type microorganism are the main controlling factors on antibacterial action.

\section{Conclusion}

Two Schiff base derivatives of cefotaxime were successfully synthesized from the condensation reaction of the antibiotic with isatin $\left(\mathrm{L}_{\mathrm{I}}\right)$ and 4-N, N-dimethylaminobenzaldehyde $\left(\mathrm{L}_{\mathrm{II}}\right)$ and their structures were characterized by elemental and thermal analysis, NMR and FTIR spectra. The coordination of the two ligands with Co(II), $\mathrm{Cd}(\mathrm{II}), \mathrm{Ni}(\mathrm{II}), \mathrm{Cu}(\mathrm{II}), \mathrm{Pd}(\mathrm{II})$, and $\mathrm{Pt}(\mathrm{IV})$ ions showed tridentate behavior with M:L mole ratio of 1:1. All complexes were of octahedral geometries except the Pd(II) complexes which had square planar structures. The biological activity of the prepared compounds was controlled by type of bacteria, functional groups of ligands and type of metal ion.

\section{References}

[1] Naz, N. and Iqbal, M.Z. (2011) Synthesis, Spectroscopic and Biological Studies of Transition Metal Complexes of Novel Schiff Bases Derived from Cephradine and Sugars. Science International (Lahore), 23, 27-31.

[2] Bukhari, I.H., Arif, M., Akbar, J. and Khan, A.H. (2005) Preparation, Characterization and Biological Evaluation of Schiff Base Transition Metal Complexes with Cephradine. Pakistan Journal of Biological Sciences, 8, 614-617.

[3] Anacona, J.R., Calvo, J. and Almanza, O.A. (2013) Synthesis, Spectroscopic and Magnetic Studies of Mono- and Polynuclear Schiff Base Metal Complexes Containing Salicilydene-Cefotaxime Ligand $\left(\mathrm{H}_{2} \mathrm{~L}\right)$. International Journal of Inorganic Chemistry, 2013, Article ID: 108740, 7 p. http://dx.doi.org/10.1155/2013/108740

[4] Kshash, A.H. (2010) Synthesis of Some Schiff Bases by Direct Condensation for Cefotaxime (Claforan) and Benzaldehyde or Its Substitutions and Study of Their Antibacterial Activity. Journal of Anbar Veterinary Science, 3, 125-132.

[5] Al-Noor, T.H., Al-Jeboori, A.T. and Aziz, M.R. (2013) Preparation, Characterization and Antimicrobial Activities of Fe(II), Co(II), Ni(II), Cu(II), and Zn(II) Mixed Ligand Complexes Schiff Base Derived from Cephalexin Drug and 4(Dimethylamino) Benzaldehyde with Nicotinamide. Advances in Physics Theories and Applications, 18, 1-8.

[6] Nigam, P., Mohan, S.W., Kundu, S. and Prakash, R. (2009) Trace Analysis of Cefotaxime at Carbon Paste Electrode Modified with Novel Schiff Base Zn(II) Complex. Talanta, 77, 1426-1431. http://dx.doi.org/10.1016/j.talanta.2008.09.026

[7] Bhrigu, B., Pathak, D., Siddiqui, N., Alam, M.S. and Ashen, W. (2010) Search for Biologically Active Isatins: A Short Review. International Journal of Pharmaceutical Science and Drug Research (IJPSDR), 2, 229-235.

[8] Pal, M., Sharma, N.K. and Jha, P.K.K. (2011) Synthetic and Biological Multiplicity of Isatin: A Review. Journal of Advanced Scientific Research, 2, 35-44.

[9] Aditya, J., Patidar, A., Manocha N. and Gupta, D. (2012) Synthesis, Characterization and Antimicrobial Activity of Novel Schiff Base of Isatin Derivatives. International Journal of Pharmaceutical Science and Drug Research (IJPSDR), 4, 260-266.

[10] Verma, M., Pandeya, S.N., Singh, K.N. and Stables, J.P. (2004) Anticonvulsant Activity of Schiff Bases of Isatin Derivatives. Acta Pharmaceutica, 54, 49-56.

[11] Silva, J.F.M., Garden, S.J. and Pinto, A.C. (2001) The Chemistry of Isatins a Review from 1975 to 1999. Journal of Brazilian Chemical Society, 12, 273-324. http://dx.doi.org/10.1590/s0103-50532001000300002

[12] Mishra, A.P., Mishra, R., Jain, R. and Gupta, S. (2012) Synthesis of New VO(II), Co(II), Ni(II) and Cu(II) Complexes with Isatin-3-Chloro-4-Floroaniline and 2-Pyridinecarboxylidene-4-Aminoantipyrine and Their Antimicrobial Studies. 
Mycobiology, 40, 20-26. http://dx.doi.org/10.5941/MYCO.2012.40.1.020

[13] Rochow, E.G. (1960) Inorganic Synthesis. McGraw-Hill, New York, 6, 218.

[14] Venkateshwarlu, E., Venkateshwar, J.R., Umasankar, K. and Dheeraj, G. (2012) Study of Anti-Inflamatory, Analgesic and Anti-Pyretic Activity of Novel Isatin Derivatives. Asian Journal of Pharmaceutical and Clinical Research, 5, $187-$ 190.

[15] Silverstien, R.M., Webster, F.X. and Kiemle, D.J. (2005) Spectrophotometric Identification of Organic Compounds. 7th Edition, John Wiley and Sons, Inc., New York.

[16] Ikotun, A.A., Egharevba, G.O., Obafemi, C.A. and Owoseni, A.O. (2012) Ring Deactivating Effect on Antimicrobial Activities of Metal Complexes of the Schiff Base of p-Nitroaniline and Isatin. Journal of Chemical and Pharmaceutical Research, 4, 416-422.

[17] Chohan, Z.H. and Jaffery, M.F. (2000) Synthesis, Characterization and Biological Evaluation of Co(II), with Cu(II), Ni(II) and Zn(II) Complexes Cephradine. Metal Based Drugs, 7, 265-269. http://dx.doi.org/10.1155/MBD.2000.265

[18] Anacona, J.R. and Silva, G.D. (2005) Synthesis and Antibacterial Activity of Cefotaxime Metal Complexes. Journal of the Chilean Chemical Society, 50, 447-450. http://dx.doi.org/10.4067/s0717-97072005000200001

[19] Al-Resayes, S.I., Shakir, M., Abbasi, A., Amin, K.M.Y. and Lateef, A. (2012) Synthesis, Spectroscopic Characterization and Biological Activities of $\mathrm{N}_{4} \mathrm{O}_{2}$ Schiff Base Ligand and Its Metal Complexes of Co(II), Ni(II), $\mathrm{Cu}(\mathrm{II})$ and $\mathrm{Zn}(\mathrm{II})$. Spectrochimica Acta Part A, Molecular and Biomolecular Spectroscopy, 93, 86-94. http://dx.doi.org/10.1016/j.saa.2012.02.099

[20] Kumar, A. and Singh, D. (2009) Metal Complexes with the Fluoroquinolone Antibacterial Agent Norfloxacin, Synthesis, Structure and Bioactivity. International Journal of Chemical Sciences, 7, 19-27.

[21] Joshi, S. (2011) Synthesis, Characterization and Biological Studies of Schiff Base Metal Complexes of Co (II), Zn (II), Ni (II), and Mn (II) Derived from Amoxicillin Trihydrate with Various Aldehydes. International Journal of Pharma and Bio Sciences, 2, 240-250.

[22] Nagajothi, A., Kiruthika, A., Chitra, S. and Parameswari, K. (2012) Synthesis and Characterization of Tetradentate Co(II) Schiff Base Complexes: Antimicrobial and DNA Cleavage Studies. International Journal of Research in Pharmaceutical and Biomedical Sciences, 3, 1768-1778.

[23] Chaluvaraju, K.C. (2011) Synthesis and Biological Evaluation of Some Isatin Derivatives for Antimicrobial Properties. Research Journal of Pharmaceutical, Biological and Chemical Sciences, 2, 541-546.

[24] Prakash, C.R., Raja, S., Selvam, T.P., Saravanan, G., Karthick, V. and Kumar, P.D. (2009) Synthesis and Antimicrobial Activities of Some Novel Schiff Bases of 5-Substituted Isatin Derivatives. Rasayan Journal of Chemistry, 2, 960968.

[25] Khalil, M.M.H. and Al-Seif, F.A. (2008) Molybdenum and Tungsten Tricarbonyl Complexes of Isatin with Triphenylphosphine. Research Letters in Inorganic Chemistry, 2008, Article ID: 746058, 4 p.

[26] Pârnău, C., Kriza, A., Popa, N. and Udrea, S. (2005) Controlled Synthesis III. Reaction of Sn(IV) and Zr(IV) with Isatins. Analele UniversităNii din Bucuresti-Chimie, Anul XIV (Serienouă), I-II, 141-146.

[27] Sharma, A. and Shah, M. (2013) Synthesis and Characterization of Some Transition Metal Complexes Derived from Bidentate Schiff Base Ligand. Journal of Applied Chemistry, 3, 62-66. http://dx.doi.org/10.9790/5736-0356266

[28] Sultana, N., Arayna, M.S. and Afzal, M. (2003) Synthesis and Antibacterial Activity of Cepharadine Metal Complexes: Part I: Complexes with Magnesium, Calcium, Chromium and Manganese. Pakistan Journal of Pharmaceutical Sciences, 16, 59-72.

[29] Sultana, N., Arayna, M.S. and Afzal, M. (2005) Synthesis and Antibacterial Activity of Cephradine Metal Complexes: part II Complexes with Cobalt, Copper, Zinc and Cadmium. Pakistan Journal of Pharmaceutical Sciences, 18, 36-42.

[30] Imran, M., Iqbal, J., Iqbal, S. and Ijaz, N. (2007) In Vitro Antibacterial Studies of Ciprofloxacin-Imines and Their Complexes with $\mathrm{Cu}(\mathrm{II}), \mathrm{Ni}(\mathrm{II}), \mathrm{Co}(\mathrm{II})$, and Zn(II). Turkjsh Journal of Biology, 31, 67-72.

[31] Anacona, J.R. and Lopez, M. (2012) Mixed-Ligand Nickel(II) Complexes Containing Sulfathiazole and Cephalosporin Antibiotics: Synthesis, Characterization, and Antibacterial Activity. International Journal of Inorganic Chemistry, 2012, Article ID: 106187.

[32] El-Said, A.I., Aly, A.A.M., El-Meligy, M.S. and Ibrahim, M.A. (2009) Mixed Ligand Zinc (II) and Cadmium(II) Complexes Containing Ceftriaxone or Cephradine Antibiotics and Different Donors. Journal of the Argentine Chemical Society, 97, 149-165.

[33] Singh, D.P., Grover, V., Kumar, K. and Jain, K. (2010) Metal Ion Prompted Macrocyclic Complexes Derived from Indole-2,3-Dione (Isatin) and O-Phenylenediamine with Their Spectroscopic and Antibacterial Studies. Acta Chimica Slovenica, 57, 775-780. 
[34] Anacona, J.R. and Osorio, I. (2008) Synthesis and Antibacterial Activity of Copper(II) Complexes with Sulphathiazole and Cephalosporin Ligands. Transition Metal Chemistry, 33, 517-521. http://dx.doi.org/10.1007/s11243-008-9074-y

[35] Nakamoto, K. (1997) Infrared and Raman Spectra of Inorganic and Coordination Compounds. 5th Edition, John Wiley and Sons, Inc., New York.

[36] Sultana, N. and Arayne, M.S. (2007) In Vitro Activity of Cefadroxil, Cephalexin, Cefatrizine and Cefpirome in Presence of Essential and Trace Elements. Pakistan Journal of Pharmaceutical Sciences, 20, 305-310.

[37] Khalifa, M.A. and Hussaan, A.M. (1996) Complexes of Some Metal Ions of Schiff Base Ligand Derived from Isatin with 2-Aminothiophenol. Journal of the Chemical Society of Pakistan, 18, 115-118.

[38] Sutton, D. (1968) Electronic Spectra of Transition Metal Complexes. McGraw-Hill Publ. Co. Ltd., New York.

[39] Lever, A.B.P. (1968) Inorganic Electronic Spectroscopy. Elsevier Publishing Company, Amsterdam, London.

[40] Figgis, B.N. (1966) Introduction to Ligand Fields. Inter-Science Publishers, a Division of John Wiley and Sons, New York, London, Sydney.

[41] Sinthuja, S.A. and Kumari, S.S. (2013) Synthesis, Spectroscopic Investigation and Antimicrobial Studies on Some Schiff Base Complexes of Cu(II) and Ni(II). Journal of Chemical and Pharmaceutical Research, 5, 303-309.

[42] Hegazy, W.H. and Gaafa, A.E.D.M. (2012) Synthesis, Characterization and Antibacterial Activities of New Pd(II) and Pt(IV) Complexes of Some Unsymmetrical Tetradentate Schiff Bases. American Chemical Science Journal, 2, 86-99. http://dx.doi.org/10.9734/ACSJ/2012/1584

[43] Geary, W.J. (1971) The Use of Conductivity Measurements in Organic Solvents for the Characterisation of Coordination Compounds. Coordination Chemistry Reviews, 7, 81-122. http://dx.doi.org/10.1016/S0010-8545(00)80009-0

[44] Ignat, I., Oprea, O., Stanica, N. and Kriza, A. (2012) Synthesis, Characterization and Thermal Behavior of Complexes of $\mathrm{Cu}(\mathrm{II}), \mathrm{Co}(\mathrm{II}), \mathrm{Ni}(\mathrm{II}), \mathrm{Zn}(\mathrm{II})$ and Cd(II) with Schiff Base Derived from 1-H-Indole-2,3-Dione and o-Aminobenzylic Alcohol. Revista De Chimie, 63, 1001-1007.

[45] Parnau, C., Olar, R., Badea, M. and Kriza, A. (2006) Thermal Behavior of Some New Isatin Complexes. Journal of Thermal Analysis and Calorimetry, 86, 217-221. http://dx.doi.org/10.1007/s10973-005-7178-6 